Pace University

DigitalCommons@Pace

Pace Law Faculty Publications

School of Law

$7-2014$

\title{
Options for Adaption to Climate Change
}

\author{
Richard L. Ottinger \\ Elisabeth Haub School of Law at Pace University \\ Pianpian Wang \\ Pace Law School \\ Kristin M. Motel \\ Pace Law School
}

Follow this and additional works at: https://digitalcommons.pace.edu/lawfaculty

Part of the Energy and Utilities Law Commons, Environmental Law Commons, and the International Law Commons

\section{Recommended Citation}

Ottinger, Richard L.; Wang, Pianpian; and Motel, Kristin M., "Options for Adaption to Climate Change" (2014). Pace Law Faculty Publications. 977.

https://digitalcommons.pace.edu/lawfaculty/977

This Article is brought to you for free and open access by the School of Law at DigitalCommons@Pace. It has been accepted for inclusion in Pace Law Faculty Publications by an authorized administrator of DigitalCommons@Pace. For more information, please contact dheller2@law.pace.edu. 
APCEL Workshop on Adaptation to Climate Change:

ASEAN and the Comparative Experiences, 17 \& 18 July 2014

\title{
OPTIONS FOR ADAPTION TO CLIMATE CHANGE
}

\author{
BY
}

\author{
Richard L. Ottinger ${ }^{1}$ \\ Pianpian Wang ${ }^{2}$ \\ Kristen M. Motel ${ }^{3}$ \\ Pace University School of Law
}

\footnotetext{
${ }^{1}$ Dean Emeritus, Pace Law School, Chair of Energy Law and Climate Change Specialty Group of the IUCN World Commission on Environmental Law.

${ }^{2}$ Pianpian Wang is a graduate of Environmental Law Program (L.L.M., 2013) at Pace University School of Law. Prior to that, She studied environmental law in Sun Yat-sen University, China.

${ }^{3}$ Kristen Motel is a law student at Pace University School of Law and is expected to obtain a J.D. with a Certificate in Environmental Law in 2015.
} 


\section{Table of Contents}

. I. Overview: Adaptation Measures in Developing Countries 3

II. Adaptation Practices on Sectors 7

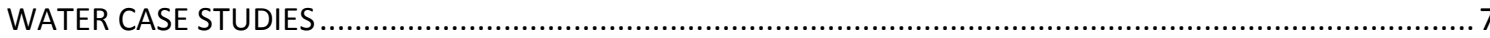

Case 1: Living Shorelines to Protect Coastal Communities from Flooding and Erosion..................... 7

Case 2: Oyster Reefs to Protect Coastlines ..................................................................................... 12

Case 3: Flood Control Structures to Protect from Flooding .................................................. 15

Case 4: Using Citizen Monitoring as an Early Warning System to Minimize Damage from Storms.... 19

Case 5: Green Infrastructure to Manage Gray Water .............................................................. 22

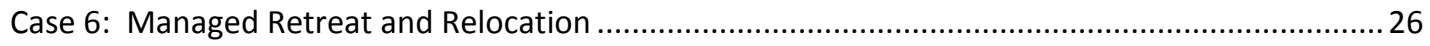

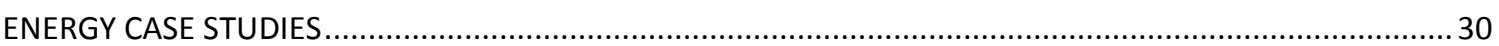

Case 7: Renewable Energy to Provide and Secure Power to Communities During Severe Weather

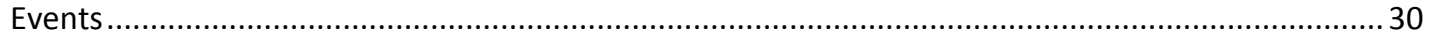

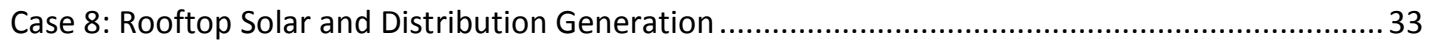

Case 9: Strengthening Powerline Transmission ........................................................................ 36

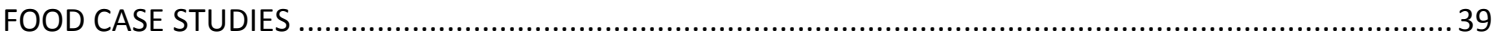

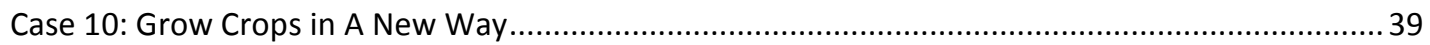

III. Interaction Between Sectors: The Water-Energy-Food Nexus 44

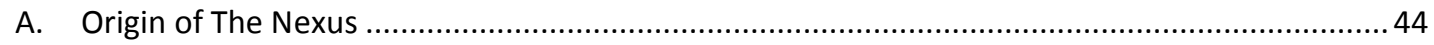

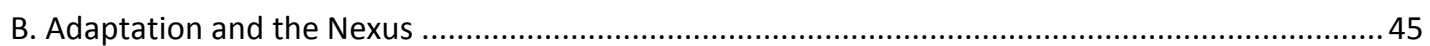

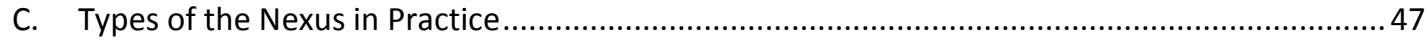

IV. Conclusion 50 


\section{. I. Overview: Adaptation Measures in Developing Countries}

In order to tackle climate change, the Intergovernmental Panel on Climate Change ("IPCC") provided a portfolio of measures: mitigation, adaptation and constant research. ${ }^{4}$ Although Article 10 of the Kyoto Protocol underlined the importance of adaptation, ${ }^{5}$ adaptation to climate change had been obtained limited attention in the early negotiations of climate talks. ${ }^{6}$ In 2010, Cancun Session of Conference of Parties ("COP”) of the United Nations Framework Convention on Climate Change ("UNFCCC") highlighted the equal importance of adaptation just as mitigation. ${ }^{7}$ Since then, increasing attention has been drawn to adaptation practice by the international society.

Typically, adaptation can be broken down into three steps: ${ }^{8}(1)$ realizing the effects of climate change ; (2) designing the activity for remediation of climate change consequences ; and (3) implementing the adaptation measures. The most important "adaptive step" is the decision-making and the way in which the activity is designed.. ${ }^{9}$ Developing countries have already realized how climate change affects them.. Change of temperature, precipitation and extreme events such as superstorms and sea level rise already have

\footnotetext{
${ }^{4}$ Intergovernmental Panel on Climate Change (IPCC), Contribution of Working Group to the Forth Assessment Report, 225 (2007), Chapter 3 is available at http://w.ww.ipcc.ch/pdf/assessment-report/ar4/wg3/ar4-wg3-chapter3.pdf , the whole report can be seen at http://www.ipcc.ch/publications_and_data/ar4/wg3/en/contents.html (last visited Mar.28, 2013).

5 “Article 10 (b) Formulate, implement, publish and regularly update national and, where appropriate, regional programmes containing measures to mitigate climate change and measures to facilitate adequate adaptation to climate change...". See Kyoto Protocol to the United Nations Framework Convention on Climate Change, available at http://unfccc.int/resource/docs/convkp/kpeng.pdf.

${ }^{6}$ The reasons are as followings: "[f]irst, the focus of the international climate change negotiations has largely been on mitigation (perhaps because attention to adaptation could been on viewed as 'giving up on mitigation')...Second, adaptation is largely undertaken at the local scale...Third, it is difficult to generalize the ways that individuals or communities are likely to adapt to specific impacts". See IPCC at 225.

${ }^{7}$ See United Nations Framework Convention on Climate Change ("UNFCCC”), The Cancun Agreement, (2010), http://cancun.unfccc.int/adaptation/ (last visited Mar. 17, 2013). Before the Cancun Agreement, "in 2001, at COP 7 in Marrakesh, Parties established the LDC work programme to develop national climate change mechanisms and build capacity, including NAPAs: Through National Adaptation Programmes of Action LDCs identify and report their adaptation needs". Also, "In 2006, at COP 12 in Nairobi, the Subsidiary Body for Scientific and Technological Advice (SBSTA) was mandated to undertake a 5 year project to address impacts, vulnerability and adaptation in relation to climate change - the Nairobi work programme." See UNFCCC, Adaptation, http://unfccc.int/focus/adaptation/items/6999.php (last visited Mar.28, 2013).
}

${ }^{8}$ Pieter Terpstra, The Difficulty of Defining Adaptation Finance, http://www.wri.org/blog/difficulty-definingadaptation-finance (last visited on Nov. 30, 2013).

${ }^{9}$ Id. 
threatened them, in particular their water, agriculture and coastal zones. ${ }^{10}$ Their adaption programs "must be an integral part of a development policy process that ensures mainstreaming of climate adaptation in all relevant sectors of society while not forgetting the other multiple drivers (social, economic, and environmental problems)". ${ }^{11}$ In other words, the ultimate goal of the adaption program design should create a link between the adaptation measures and overall sustainable development. The measures will need to be different for each country since "adaptation needs to be context specific and dependent on the resources available to the impacted domain". ${ }^{12}$

Therefore, developing countries need to conduct analyses of climate change impacts and vulnerability assessments in a top-down and bottom-up adaptation planning. ${ }^{13}$ This is because

[i]t is now increasingly recognized that, for poor communities, adaptation approaches that are rooted in local knowledge and coping strategies, and in which communities are empowered to take their own decisions, are likely to be far more successful than top-down initiatives. ${ }^{14}$

However, adaptation cost and adaptive capacity are two barriers in developing countries. On a regional basis, the East Asia and Pacific Region bears the highest adaptation cost according to some economic analyses. ${ }^{15}$ With regard to adaptive capacity, developed countries have more strengths on adaptation development than developing countries because of their greater resources and often better governance systems, technical support and quality of national institutions.

\footnotetext{
${ }^{10}$ See UNFCCC, Climate Change: Impacts, Vulnerabilities and Adaptation in Developing Countries, 18-26 (2007), available at http://unfccc.int/resource/docs/publications/impacts.pdf.

${ }^{11}$ Ole Mertz, Kristen Halsnaes, Jørgen E. Olesen, Kjeld Rasmussen, Adaptation to Climate Change in Developing Countries, 747 (2008), available at http://www.researchgate.net/profile/Jorgen_Olesen2/publication/23966336_Adaptation_to_climate_change_in_developing_ countries/file/9fcfd50a940e0129ee.pdf.

${ }^{12}$ Aondover Tarhule, Climate Change Adaptation in Developing Countries: Beyond Rhetoric, 173-174 (2012), available at http://cdn.intechopen.com/pdfs-wm/25931.pdf.

${ }^{13}$ Valerie Nelson, Richard Lamboll, Adele Arendse, Climate Change Adaptation, Adaptive Capacity and Development Discussion Paper, 3(2008), available at http://climateanddevelopment.nri.org/background_papers/nelson_lamboll_and_arendse_climate_change_adaptation.pdf.

${ }^{14}$ IIED, Participatory Learning and Action: Community-based Adaptation to Climate Change, 3, available at http://pubs.iied.org/pdfs/14573IIED.pdf.

${ }^{15}$ World Bank, The Cost to Developing Countries of Adapting to Climate Change: New Methods and Estimates, 4 (2010), available at http://siteresources.worldbank.org/INTCC/Resources/Executivesummary.pdf.
} 
Various partnerships that aim to improve adaptive capacity and resilience have been carried out in developing countries. However, it is a long-term process and takes substantial time to see the results. Under the pressure of climate change, instantly effective adaptation measures would be helpful to developing countries. This paper proposes a series of adaptation paths that can be promoted and replicated under different circumstances regardless of different governance structures.

\section{Summary Chart}

\begin{tabular}{|c|c|c|c|c|c|c|}
\hline Programs & $\begin{array}{l}\text { Adap } \\
\text { ting } \\
\text { Sector }\end{array}$ & $\begin{array}{c}\text { Implementing } \\
\text { Organization/Project } \\
\text { Developer }\end{array}$ & $\begin{array}{c}\text { Staff } \\
- \\
\text { Training } \\
\text { Needed? }\end{array}$ & $\begin{array}{l}\text { Funding } \\
\text { Size }\end{array}$ & $\begin{array}{l}\text { For } \\
\text { Urban or } \\
\text { Rural }\end{array}$ & $\begin{array}{c}\text { Progra } \\
\text { m Cycle }\end{array}$ \\
\hline $\begin{array}{l}\text { Living } \\
\text { Shorelines }\end{array}$ & Water & $\begin{array}{l}\text { Government and } \\
\text { Citizens }\end{array}$ & Yes & $\begin{array}{l}\quad \text { Initial plan } \\
\text { development } \\
\text { training cost } \\
\text { funded by the } \\
\text { government. } \\
\text { Implementation } \\
\text { funded by the } \\
\text { Government } \\
\text { and citizens }\end{array}$ & $\begin{array}{l}\text { Rural or } \\
\text { urban } \\
\text { areas with } \\
\text { no "hard" } \\
\text { shoreline } \\
\text { protection } \\
\text { structures }\end{array}$ & $\begin{array}{l}\text { A short } \\
\text { installation } \\
\text { period with } \\
\text { results that } \\
\text { can be seen } \\
\text { within a } \\
\text { short-mid } \\
\text { period of } \\
\text { time }\end{array}$ \\
\hline $\begin{array}{l}\text { Rebuilding } \\
\text { Oyster Reefs }\end{array}$ & Water & $\begin{array}{l}\text { Government, } \\
\text { NGOs, or Research/ } \\
\text { Educational Institution }\end{array}$ & Yes & $\begin{array}{l}\quad \text { Initial } \\
\text { creation cost } \\
\text { and subsequent } \\
\text { monitoring } \\
\text { funded by the } \\
\text { government, } \\
\text { NGO, or } \\
\text { institution }\end{array}$ & Both & $\begin{array}{l}\text { A moderate } \\
\text { installation } \\
\text { period with } \\
\text { results that } \\
\text { can be seen } \\
\text { within a } \\
\text { short- mid } \\
\text { period of } \\
\text { time }\end{array}$ \\
\hline $\begin{array}{l}\text { Flood Gates } \\
\text { and Flood } \\
\text { Protection } \\
\text { Systems }\end{array}$ & Water & $\begin{array}{l}\text { Government or } \\
\text { Private Corporation }\end{array}$ & Yes & \begin{tabular}{l}
\multicolumn{1}{c}{ Initial } \\
equipment and \\
training cost \\
funded by the \\
government or \\
corporation
\end{tabular} & Urban & $\begin{array}{l}\text { A short } \\
\text { planning and } \\
\text { training } \\
\text { period with } \\
\text { results seen } \\
\text { during at the } \\
\text { initial use }\end{array}$ \\
\hline $\begin{array}{l}\text { Citizen } \\
\text { Monitoring }\end{array}$ & Water & \begin{tabular}{l}
\multicolumn{1}{c}{ Government, } \\
NGOs, or Research/ \\
Educational Institution \\
and Citizens
\end{tabular} & Yes & $\begin{array}{l}\quad \text { Initial } \\
\text { equipment and } \\
\text { training cost } \\
\text { funded by the } \\
\text { government or }\end{array}$ & Both & $\begin{array}{l}\text { A moderate } \\
\text { set up time } \\
\text { and ongoing } \\
\text { program. } \\
\text { Requires }\end{array}$ \\
\hline
\end{tabular}




\begin{tabular}{|c|c|c|c|c|c|c|}
\hline & & & & institution & & $\begin{array}{l}\text { consistent } \\
\text { coordination } \\
\text { between } \\
\text { citizens and } \\
\text { funding } \\
\text { organization }\end{array}$ \\
\hline $\begin{array}{l}\text { Displacement } \\
\text { Management }\end{array}$ & Water & Government & Yes & $\begin{array}{l}\quad \text { Continuous } \\
\text { funding } \\
\text { required to } \\
\text { evacuate, } \\
\text { transport, and } \\
\text { resettle } \\
\text { populations }\end{array}$ & Both & $\begin{array}{l}\text { Long term } \\
\text { and ongoing } \\
\text { program, } \\
\text { becoming } \\
\text { more } \\
\text { frequent with } \\
\text { increased } \\
\text { storm events }\end{array}$ \\
\hline $\begin{array}{c}\text { Green } \\
\text { Infrastructure }\end{array}$ & Water & $\begin{array}{l}\text { Government and } \\
\mathrm{NGOs}\end{array}$ & Yes & $\begin{array}{l}\quad \text { Grant } \\
\text { sources include } \\
\text { federal, state } \\
\text { and private } \\
\text { funding }\end{array}$ & Both & $\begin{array}{l}\text { Started in } \\
2001 \text { and } \\
\text { requires } \\
\text { consistent } \\
\text { input and } \\
\text { maintenance } \\
\end{array}$ \\
\hline $\begin{array}{c}\text { Micro- } \\
\text { hydropower }\end{array}$ & Energy & $\begin{array}{l}\text { Government and } \\
\mathrm{NGOs}\end{array}$ & Yes & $\begin{array}{l}\quad \text { Funded by } \\
\text { the local } \\
\text { government or } \\
\text { non-profit } \\
\text { group. }\end{array}$ & $\begin{array}{l}\text { Both, } \\
\text { Rural } \\
\text { would be } \\
\text { simplest }\end{array}$ & $\begin{array}{l}\text { Initial } \\
\text { training and } \\
\text { start-up is } \\
\text { about one } \\
\text { year and } \\
\text { requires } \\
\text { consistent } \\
\text { maintenance } \\
\text { and training }\end{array}$ \\
\hline $\begin{array}{l}\text { Rooftop } \\
\text { Solar and } \\
\text { Community } \\
\text { Distributed } \\
\text { Generation }\end{array}$ & Energy & $\begin{array}{l}\text { Religious Group } \\
\text { (NGOs) }\end{array}$ & No & $\begin{array}{l}\text { Funded by } \\
\text { the religious } \\
\text { group }\end{array}$ & Both & $\begin{array}{l}\text { A short } \\
\text { installation } \\
\text { period with } \\
\text { long pre- } \\
\text { planning and } \\
\text { technical } \\
\text { preparation }\end{array}$ \\
\hline $\begin{array}{l}\text { Strengthening } \\
\text { Power } \\
\text { Transmission }\end{array}$ & Energy & Utility Companies & Yes & $\begin{array}{l}\text { Funded by } \\
\text { the utility } \\
\text { company }\end{array}$ & Urban & $\begin{array}{l}\text { A mid-long } \\
\text { term } \\
\text { upgrade }\end{array}$ \\
\hline $\begin{array}{l}\text { Grow Crops in } \\
\text { A New Way }\end{array}$ & Food & Government & Yes & $\begin{array}{l}\quad \text { Funded by } \\
\text { local } \\
\text { governments }\end{array}$ & Both & $\begin{array}{l}\text { Results can } \\
\text { be seen } \\
\text { within a } \\
\text { short-mid } \\
\text { long period }\end{array}$ \\
\hline
\end{tabular}




\begin{tabular}{|l|l|l|l|l|l|l|}
\hline $\begin{array}{l}\text { Coordination } \\
\text { of the Water- } \\
\text { Energy-Food } \\
\text { Nexus }\end{array}$ & $\begin{array}{l}\text { Water, } \\
\text { Energy } \\
\text { and Food }\end{array}$ & Government & No & $\begin{array}{l}\text { Funded by } \\
\text { local } \\
\text { governments }\end{array}$ & Urban & $\begin{array}{l}\text { Consistent } \\
\text { Coordination } \\
\text { between } \\
\text { departments }\end{array}$ \\
\hline
\end{tabular}

Figure-1

\section{Adaptation Practices by Sectors}

One striking characteristic of developing countries is that agriculture accounts for a large part of gross domestic product and employment. ${ }^{16}$ Thus, there are particular concerns within the agricultural sector, and it is believed that adaptation centered on agriculture in developing countries would have chain effects on their water and energy as well. In this section, ten case studies that focus on water, energy and food present effective adaptation measures for these important sectors.

Since developing countries generally have a lower capacity to adapt to climate changes, simple, economical and innovative principles are prerequisites in the selection of these case studies.

\section{WATER CASE STUDIES}

\section{Case 1: Living Shorelines to Protect Coastal Communities from Flooding and Erosion}

Coastal habitats act as the front line for communities against tropical weather events.

Shoreline restoration is important to protect marshes that serve as a protective barrier for coastal communities against storm surge and waves during severe weather events. ${ }^{17}$ Shoreline restoration also helps prevent coastal erosion, which can dramatically alter the landscape of a community and cause damage to cities and towns. Elements of shoreline

\footnotetext{
${ }^{16}$ Alok Kumar, Lecture 2: Major Characteristics of Developing Countries, 4, University of Victoria, available at http://web.uvic.ca/ kumara/econ420/characteristics-dev.pdf.

${ }^{17}$ La. CoAstal Prot. AND Restoration Auth., Featured Projects, http://coastal.la.gov/our-work/projects/featured-projects/ (last visited June 30, 2014).
} 
restoration projects include mangrove restoration and other headland restoration measures like the restoration of dunes and beaches, marsh creation, implementation of oyster barrier reefs, ${ }^{18}$ and built shoreline protection measures like sea walls and breakwaters. ${ }^{19}$

\section{A. How do Living Shorelines Work?}

Mangrove destruction has left many coastlines vulnerable to increased storm surge and erosion. An effective shoreline protection measure is to rebuild mangrove belts in grids to prevent coastal erosion. Erosion can be slowed by building grids of mangroves by first starting with trellises of small permeable bundles made of branches and bamboos. ${ }^{20}$ This allows for maximum sediment capture while minimizing the wave force, helping to restore marshlands around each bundle. ${ }^{21}$ These grids create low-energy conditions that restore land so that mangroves can be planted and eventually re-colonized onto the belts. ${ }^{22}$ By building mangroves in grids, space is freed up for other coastal activities like aquiculture, recreation, and fishing. Furthermore, evidence shows that restoring mangroves in grids also helps restore crab populations. ${ }^{23}$

Currently, this practice is being implemented in the Island Pacific nations of Sri Lanka, Indonesia, and in Thailand, Malaysia, and India, and also in western African countries like Guinea Bissau and Sierra Leone. ${ }^{24}$ In some locations the practice is being implemented using a "Bio Rights Microcredit Scheme" that combines these environmental improvements with

\footnotetext{
${ }^{18}$ See supra Cast Study 2: Oyster Barrier Reefs.

${ }^{19}$ La. CoAstal Prot. And Restoration Auth., supra note 14.

${ }^{20}$ Gerard van Raalte, BwN for Coastal Resilience. A Pilot on Rehabilitation of a Mangrove-mud Coast in Timbul Sloko (Java, Indonesia), BUILDING WITH NATURE (Feb. 2, 2014) https://publicwiki.deltares.nl/display/BWN/BwN+for+coastal+resilience (explaining a pilot study on rehabilitation of a mangrove-mud coast).

${ }^{21} I d$.

${ }^{22} I d$.

${ }^{23}$ See Walton M.E.; Le Vay L.; Lebata J.H., Binas J. \& Primavera J.H, Assessment of the Effectiveness of Mangrove Rehabilitation Using Exploited and Non-exploited Indicator Species, BIOLOGICAL CONSERVATION 138, 180-188 (2007).

${ }^{24}$ These mangrove practices are being implemented by non-profit agencies like Deltares and Wetlands International. See DELTARES, http://www.deltares.nl/en (last visited June 30, 2014); WETLANDS INTERNATIONAL, http://www.wetlands.org/Whatwedo/Mangrovesforcoastalresilience/tabid/174/Default.aspx (last visited June 30, 2014). Wetlands International has partnered with the Indonesian government service BPDAS-PB of the Ministry of Forestry to coordinate the engagement of government agencies in data gathering, fieldwork and policy dialogues regarding mangrove restoration. The Indonesian Government Centre for Marine Resource Survey is undertaking a detailed mapping of mangrove status and distribution in Indonesia. See Pieter Van Eijk, Mangrove Capital, wETLANDS INTERNATIONAL, available at http://www.wetlands.org/LinkClick.aspx?fileticket=gu1B1W9FeFo\%3D\&tabid=56 (last visited June 30, 2014).
} 
the goal of poverty reduction. ${ }^{25}$ Funding is given to communities with the promise that they will undertake mangrove restoration. ${ }^{26}$ The environmentally friendly economic development resulting from these projects is further funded, and a condition for receiving the financial support is an agreement that the countries will refrain from returning to practices that damage the mangroves. ${ }^{27}$ This scheme enables local communities to manage mangroves sustainably.

In addition to restoring mangroves, shorelines restoration projects, sometimes known as "living shorelines" are being implemented in many different countries and locations. ${ }^{28}$ This process involves altering and restoring shorelines to protect them from erosion using "non hard" techniques like plantings, beach nourishment, breakwaters, sills, and low profile oyster reefs. The "hard" techniques used in the past, like seawalls, bulkheads, and rock revetments, are expensive and do not adjust to changing weather needs because they do not allow wetlands to retreat towards the land as sea level rises. ${ }^{29}$ Additionally, the machinery used to build "hard" techniques can be disruptive and cause damage to coastal wetlands.

Living shorelines can be created through non-structural stabilization or hybrid stabilization, depending on wave energy. Usually for the portion of the shoreline closest to

\footnotetext{
${ }^{25}$ WeTLANDS INTERNATIONAL, Bio-rights: Micro-credit for Nature Conservation, http://www.wetlands.org/Aboutus/Howwework/Biorights/tabid/2732/Default.aspx (last visited June 30, 2014).

${ }^{26} I d$.

${ }^{27} I d$.

${ }^{28}$ In the United States, states with active shoreline restoration projects include Delaware, Florida, Louisiana, Maryland, New York, North Carolina, Texas, and Virginia. Louisiana has managed to benefit over 110,000 acres of coastal habitat through restoration. See La. Coastal Wetlands Planning \& Restoration Act Program, CWPRA Legislation, $\mathrm{http} / / /$ lacoast.gov/new/About/ (last visited June 30, 2014). New York City is conducting wetland restoration projects at beach sites to improve natural flooding patterns. See Jonathan D. Cybulski, Transportation Infrastructure Resiliency, 10 (HARVARD UnIVERSITY, Volpe Center Report No. DOT-VNTSC-14-02), available at

http://www.bv.transports.gouv.qc.ca/mono/1149029.pdf. In Belgium, forty percent of the coastline is protected using soft solutions such as planting brushwood, sand fences, and planting of Marram grass. See Toon Verwaest, Nourishment Practices in the North Sea Countries (2000), available at http://www.masterpiece.dk/UploadetFiles/11320/25/Nourishment_practices_in_the_North_Sea_Countries_may_2000.pdf. Along the Black Sea, wetlands on the Danube River floodplain are being restored by constructing salt marshes along sea dikes to mitigate the power of incoming waves. See id. Canada's shoreline restoration programs in the Caribou Islands, Nova Scotia and in Point Ellice Park in Victoria, British Columbia, include, "soft armoring" and "green shores" which build brush walls and add biomass. See The Arlington Group Planning And Architecture Inc., Sea Level Rise Adaption Primer (2013), available at http://issuu.com/scbc/docs/slr-primer.

${ }^{29}$ NOAA, Alternate Shoreline Stabilization Methods,

http://coastalmanagement.noaa.gov/initiatives/shoreline_stabilization.html (last visited June 30, 2014); N.C. COASTAL FED'N, Terminal Groins 101, http://www.nccoast.org/Content.aspx?key=79e38ba1-e221-4033-a2b4-

86f17b374a7f\&title=Terminal+Groins. (last visited June 30, 2014). North Carolina no longer allows hard structures to be built because. The state recognizes they are no longer a sustainable solution. See NOAA COASTAL SERVS. CTR., North Carolina Sea Wall Ban Stands Up to Legal Challenge (March/ April 2000), available at http://www.csc.noaa.gov/magazine/2000/02/nc.html.
} 
land, riparian vegetation is restored, banks are graded, and fiber logs are put into place. ${ }^{30}$ Closer towards the water, a tidal marsh is created and vegetation is further enhanced. ${ }^{31}$ Some projects will also use beach nourishment, dune restoration, and marsh toe revetment. ${ }^{32}$ Closest to the water, marsh stills and marshes with groins are created. ${ }^{33}$ Depending on the wave energy of the area, there can be a living breakwater or oyster reef located offshore to further protect the coast. ${ }^{34}$

\section{B. Implications for Further Replication}

Implementing a shoreline restoration program has many benefits; most importantly; it is a method to ensure less property loss during storms by preventing bank erosion. Living shorelines have a low-technology cost because they provide a natural solution. These programs are also aesthetically pleasing and conducive to recreation activities because they protect the beach.

Aside from minimizing coastal erosion and providing protection during storms, restored shorelines help improve coastal water quality by filtering impurities and stormwater runoff during rain events. Furthermore, the living shorelines restore marine habitat and spawning grounds for marine life, improving the local fishing industry. When storms create removal of shading and vegetation from shoreline they can cause shallow water temperatures to rise, depleting oxygen and adversely affecting fish. Consequently, shoreline restoration improves wildlife habitat by providing cover and keeping temperature and oxygen at sustainable levels.

It can be difficult to implement a shoreline restoration program in areas where the shoreline is privately owned. When land is privately owned, it is up to individual property owners to make informed decisions about managing their shorelines. If there are buildings directly adjacent to the beach, it is more difficult to locate an area suitable for restoring

\footnotetext{
${ }^{30}$ Va. Ctr. For Coastal Res. MGmt., Living Shorelines Program, http://ccrm.vims.edu/livingshorelines/ (last visited June 30, 2014).

${ }^{31} I d$.

${ }^{32} I d$.

${ }^{33} I d$.

${ }^{34} I d$.
} 
wetlands. Shorelines restoration will also not be useful in areas where most of the shoreline is already hardened; the seawalls first would have to be demolished.

Each site must be evaluated for its distinct features, which requires data collection from fundamental monitoring. For example, restored shorelines are not the best protection method for areas with high wave energies. When deciding to implement shoreline restoration, it is helpful to have private contractors specializing in marine areas trained to correctly plant the vegetation and install the techniques. Also, when considering whether to build mangrove belts, the coastal conditions must be conducive to mangrove growth. "[M]angroves can only be successfully restored if the abiotic conditions are optimal (bathymetry, fresh water and sediment input)." ${ }^{, 35}$

Living shorelines programs are typically implemented by a Coastal Planning Commission. The Commission develops the program after a Shoreline Management Plan is created to identify areas of importance and agencies with authority and responsibility for implementing the program. ${ }^{36}$ The Plan requires data and monitoring of the prioritized sites to identify the areas of high priority. The Shoreline Management Plan is then adopted, usually by town boards and carried out by municipal officials or local citizen's organizations. ${ }^{37}$ These municipal officials or local citizen's organizations, where available, encourage landowners to implement living shorelines by communicating the protection and benefits previously mentioned. This communication can be in the form of pamphlet distribution, town hall meetings, or through information posted on websites. Successful shoreline restoration programs have incorporated free training for the local citizens' organizations, landowners and shoreline contractors, a list of local native plants that will thrive in tidal areas, a planting and cost guide for these plants, public demonstration areas where citizens can see how the shorelines are being restored, and a decision tree for the local government agency responsible for making the decisions. ${ }^{38}$

Shorelines restoration programs require multi- government agency collaboration. These programs typically involve many divisions of local government including Building and

\footnotetext{
${ }^{35}$ Gerard van Raalte, supra note 17.

${ }^{36}$ VA. CTR. For COASTAL Res. MgmT., supra note 27.

${ }^{37} I d$.

${ }^{38}$ Va. Ctr. FOR CoAstal Res. Mgmt., Living Shorelines Program Frequently Asked Questions, http://ccrm.vims.edu/livingshorelines/faq.html (last visited June 30, 2014).
} 
Zoning, Fish and Game, Tourism, Economic, Recreation, and Environmental Protection departments. ${ }^{39}$ These departments ideally should be involved in the creation of theShoreline Management Plan, evaluate its effectiveness, and raise any concerns they have about the program implementation. ${ }^{40}$ Specific responsibilities of each agency should be outlined in the Plan.

\section{Case 2: Oyster Reefs to Protect Coastlines}

Oyster reefs protect the coastline from erosion by slowing wave velocity and storm surge. Up to ninety percent of the energy from wind-generated waves can be absorbed by these reefs. ${ }^{41}$ Reefs not only preserve the coastline, they protect coastal communities from property damage and shield them from the economically destructive effects of beach erosion. Creating oyster reefs not only protects the shoreline, but it also restores estuary ecosystems and provides more stock for commercial fishermen. Adult oyster reefs can significantly increase coastal water quality by filtering it.

\section{A. How does Oyster Reef Creation and Restoration Work?}

Oyster reefs are built to act as a barrier against coastal erosion to break incoming waves on the reef. Juvenile oysters are raised in a hatchery and then "attach, set, and grow on shell substrate. ${ }^{42}$ New reefs constructed from marl, a sedimentary rock made out of limestone, can be constructed using bags of recycled oyster shells. ${ }^{43}$ Oyster larvae attach to the structure and grow while additional oyster larvae attach to older shells, creating a substantial reef.

As part of the New York and New Jersey Baykeeper's Oyster Restoration Program, microscopic oyster larvae are released into 450 gallon saltwater tanks containing bags of

\footnotetext{
${ }^{39} I d$.

${ }^{40}$ In the United States, Virginia has a "networked program," meaning the program relies on a network of state agencies and local governments to administer enforceable laws and regulations that protect wetlands, dunes, fisheries, subaqueous lands, and air and water within Virginia's coastal zone. See Id.

${ }^{41}$ NOAA, Coral Reef Conservation Program, Coastal Protection, http://coralreef.noaa.gov/aboutcorals/values/coastalprotection/ (last updated May 13, 2011). http://www.nature.org/ourinitiatives/regions/northamerica/unitedstates/louisiana/oyster-reef-restoration-in-louisiana.xml.

${ }^{42}$ New YoRK New JeRSEY BAYKeEPER, Oyster Restoration Program, http://nynjbaykeeper.org/resources-programs/oysterrestoration-program/ (last visited June 30, 2014).

${ }^{43} I d$.
} 
clam shells to start the reef. ${ }^{44}$ The larvae attach and grow on the shells at the hatchery, and once the oysters have grown for two months, they are released onto the new oyster reefs. ${ }^{45}$ The new reefs are usually deployed off of a pier. ${ }^{46}$ The structures are placed sub tidally, because two to three feet of water must remain above the oysters during the lowest tide to ensure oyster survival. ${ }^{47}$ In New York City's Soundview Park, 125 cubic yards of shells were placed by a barge and deposited in the intertidal region around existing rock outcroppings. ${ }^{48}$ The shell reef provides substrate on which new oysters can attach.

Louisiana has three oyster reef projects taking place in Vermillion Bay, Grand Isle and St. Bernard Parish that are being built to protect the coastline from erosion and absorb wave energy during storms. ${ }^{49}$ Besides restoring the coastline after Hurricane Katrina, Louisiana also needed to stimulate its commercial fishing economy. Seventy percent of the world's oysters come from the Gulf of Mexico, and oyster reefs are a viable way to protect and increase the oyster population and create commercial fishing jobs. ${ }^{50}$ Louisiana has put Louisiana State University in charge of monitoring the conditions and health of theses oyster reefs. ${ }^{51}$

\section{B. Implications for Further Replication}

The success rate for oyster reef creation or restoration programs has been high. ${ }^{52}$ For example, the oyster project at Naval Weapons Station Earle in New Jersey had ninety percent

\footnotetext{
${ }^{44} I d$.

${ }^{45} I d$.

${ }^{46} I d$.

${ }^{47} I d$.

${ }^{48} I d$.

49 Louisiana Coastal Protection AND Restoration Authority, Featured Projects, http://coastal.la.gov/ourwork/projects/featured-projects/ (last visited June 30, 2014).

${ }^{50}$ The NATURe CONSERvancy, Restoring Oyster Reefs for People and Nature, http://www.nature.org/ourinitiatives/regions/northamerica/unitedstates/louisiana/oyster-reef-restoration-in-louisiana.xml (last visited June 30, 2014).

${ }^{51} I d$.

${ }^{52}$ In North Carolina's Alligator River an oyster reef was created in Swanquarter National Wildlife Refuge to break incoming waves, prevent storm damage, and control erosion. The project also provides more oysters to help North Carolina's shellfish economy and improves offshore wildlife habitat. See The NAture Conservancy, Building Oyster Reefs off the North Carolina Shore: Good for Plates and People,

http://www.nature.org/ourinitiatives/regions/northamerica/unitedstates/northcarolina/explore/oyster-reef-restoration-innorth-carolina-1.xml (last visited June 30, 2014). Texas's oyster reef creation at Mad Island Marsh Preserve has also been successful. See The NATURe Conservancy, Southern Solutions for a Global Problem,

http://www.nature.org/cs/groups/webcontent/@web/@southcarolina/documents/media/prd_014253.swf (last visited June 30,
} 
of the oysters on the reefs survive the winter. ${ }^{53}$ There is an initial start-up cost to this program; however, once the reefs are placed into the water, the only continuing cost is for monitoring reef success. Part of that start-up cost includes testing oyster support structures to determine which structures will have the highest oyster survival and growth rates. Finding the initial funding to implement the program can be a challenge.

The water quality in which the oyster reefs will be placed must be taken into consideration when choosing a location for the reefs. Creating oyster reefs in waters that are contaminated will create not only a public health issue, but will also prevent fishermen and citizens from harvesting and profiting from contaminated oysters. ${ }^{54}$ However, as with any water where shellfish harvesting is restricted or prohibited, posted signs and educating the local population can be an effective way to prevent the ingestion of contaminated food. Patrolling the waters in boats is another way to ensure contaminated oysters will not be harvested. ${ }^{55}$

2014). New York is investigating installing offshore breakwater systems using oyster reefs at Totten and next to Great Kills Harbor. See New York CiTY DePARTMENT OF City PlanNing, Urban Waterfront Adaptive Strategies (2013) available at http://www.nyc.gov/html/dcp/pdf/sustainable_communities/urban_waterfront.pdf.

${ }^{53}$ NEW YORK NEW JERSEY BAyKeEPER, supra note 39.

54 The NATURe CONSERVANCY, supra note 47.

${ }^{55}$ NeW York New JeRSEy BAyKeEPER, supra note 39. 


\section{Case 3: Flood Control Structures}

Flood control structures are an effective way to protect buildings and communities from floods caused by storms. When planned and used correctly, water control structures can reduce the level of cleanup after storms, helping cities recover from severe storms more quickly. The priority is to use flood control structures to protect essential emergency resources, specifically hospitals, communication and data centers, schools, and fire departments. In the United States, flood control structures are being installed in coastal cities to protect from rising floodwaters. ${ }^{56}$ Globally, many cities are incorporating the use of water control structures into their emergency and future planning efforts. ${ }^{57}$

\section{A. How do Flood Control Structures Work?}

There are different kinds of flood control structures that can be used. Flashboard risers are structures installed in a drainage outlet that allow water in the drainage outlet to be raised or lowered as needed; when the risers are lowered, the drainage occurs less quickly. ${ }^{58}$ When

\footnotetext{
${ }^{56}$ New York City is installing twenty-five tidal floodgates along Beach Chanel drive and other waterfront areas to reduce the risk of flooding and make them more resilient. See NEW YoRK CITY, Coastal Protection Report: Mayor Bloomberg Details Progress on Resiliency Projects Outlined in the City's Long-Term Plan to Protect City Against the Effects of Climate Change on Hurricane Sandy Anniversary, Oct. 29, 2013, available at http://www1.nyc.gov/office-of-the-mayor/news/34813/mayor-bloomberg-details-progress-resiliency-projects-outlined-the-city-s-long-term-plan-to/\#/0 (last visited June 30, 2014). This investment prevents water from flooding the streets and overpowering the storm drains. In low-income areas like Coney Island Commons, the housing is being re-designed to include deployable flood panels that will minimize damage in the future. See id. An integrated flood protection system involving flood gates and raised entrances to tunnels that are vulnerable to flooding is being implemented in Hunts Point, East Harlem, lower east side Manhattan, Hospital Row, Red Hook, Staten Island, and Newton Creek areas of New York City. See id. Floodgates are also being used to protect the subway system and public transit hubs. See id. In New Orleans, the city is building a perimeter defense system consisting of storm surge barriers in front of the city. Robert Reid, Defending New Orleans, Civil Engineering (Nov. 2013) available at http://www.asce.org/uploadedFiles/Awards/OPAL_Awards/ce_Inner\%20Harbor_Navigation_Canal_Surge_Barrier.pdf. In North Carolina, water control structures that have flashboard risers and tidal gates are being used on the Alligator River to restore hydrologic regime and prevent saltwater intrusion. THE NATURE CONSERVANCY, Climate Change Adaptation: Alligator River National Wildlife Refuge, available at http://www.nature.org/images/climate-change-adaptaion-in-thealligator-river-nwr.pdf (last visited June 30, 2014).

${ }^{57}$ In Venice, Italy, the MOSE Project is currently underway. This project involves installing locks to protect Venice from flooding. The locks will be activated when the water is 3.6 feet above normal levels. Sylvia Poggioli, MOSE Project Aims to Part Venice Floods, NATIONAL Public RAdio (Jan. 7, 2008), available at http://www.npr.org/templates/story/story.php?storyId=17855145. Only four of the anticipated seventy-eight gates have been installed so far due to economic issues in the country. See id. When completed, the floodgates will extend more than a mile, blocking three inlets to the lagoon. See ITALY, Coastal Flood Risk Italy, http://www.climateadaptation.eu/italy/coastalfloods/ (last visited June 30, 2014). In Tokyo, Super Levees are used to protect the city during severe rain events. See Cameron Allan McKean, Tokyo Building Enormous "Super-Levees" to Hold Back Its River, NeXT CiтY, 30 (Dec. 4, 2013), available at http://nextcity.org/daily/entry/tokyo-is-building-enormous-super-levees-to-hold-back-its-river. The levees are designed for extreme events in dense urban areas. The levees consist of a broad river embankment that can withstand overflow to prevent destruction. The super levee is 10 meters high and 300 meters wide, and resistant to seepage and earthquakes. See id.; Le Thu Trang, Flood Adaptive Cities, Preliminary Project Report (May 2013), available at http://www.deltainterventions.com/wp-content/uploads/2012/09/p4report_Trang-Le.pdf.
}

\footnotetext{
${ }^{58}$ See U.S. Fed. EMERgency Mgmt. Agency, Floodproofing Non-Residential Buildings, Chp. 4 Other Flood Protection Measures (Jul. 31, 2013), available at http://www.fema.gov/media-library-data/2c435971150193efc6a6ba08f2403863/P936_sec4_508.pdf.
} 
more flashboards are added to the riser, the drainages rate is decreased and the water level in the surrounding area will rise. ${ }^{59}$ Flashboard risers lessen the amount of water running through the storm drain, so the intensity and frequency of combined sewer overflows is reduced, and this minimizes health risks due to flooding.

Oppositely, flood or tidal gates can be adjusted to control or stop water entry from a storm surge and prevent the intrusion of floodwaters while also deflecting flood borne debris. ${ }^{60}$ Permanent floodwalls are the simplest and most cost effect to design and construct. These are usually made of reinforced concrete or masonry, sometimes with steel reinforcing bars embedded in the core. ${ }^{61}$ Floodwalls are usually placed away from buildings so that structural modifications are not required. ${ }^{62}$ Permanent floodwalls are the best suited for geographical areas that experience high storm surge and rapid flowing water.

Temporary floodwalls can be easily assembled and are moved into place and anchored where necessary. ${ }^{63}$ The barriers are then filled with water or sand to hold them in place. In the United States on the Mississippi River, invisible floodwalls are utilized. ${ }^{64}$ The "invisible floodwalls" are steel walls that can quickly be put up at the first warning of a flood, and when not needed, they can be taken down and stored. ${ }^{65}$ These steel floodwalls are also being deployed in New York City, particularly in areas that experienced catastrophic flooding during Hurricane Sandy. ${ }^{66}$ The Verizon Headquarters Building has invested in a nine-foot

\footnotetext{
${ }^{59}$ See id.

${ }^{60}$ See id.

${ }^{61}$ See id.

${ }^{62}$ See id.

${ }^{63}$ See id.

${ }^{64}$ See Brian Johnson, Flood Wall Project Pays off Early for St. Paul's Downtown, FinANCE \& CommerCe (Sep. 29, 2010), available at http://finance-commerce.com/2010/09/flood-wall-project-pays-off-for-st-paul-downtown-airport/; FLOOD Control America, Removable Flood Wall Project- St. Paul Downtown Airport, http://floodcontrolam.com/projects/floodwall-st-paul/.

${ }^{65}$ Flood Control AmericA, How the Floodwall Works, http://floodcontrolam.com/works/ (last visited June 30, 2014). Flood Control America is the manufacturer of the temporary floodwalls used on the Mississippi River.

${ }^{66}$ David W. Dunlap, A Modern Flood Barrier Aims to Protect Verizon's Landmark Building, N.Y. Times (Oct. 30, 2013), available at http://www.nytimes.com/2013/10/31/nyregion/a-modern-flood-barrier-aims-to-protect-verizons-landmarkbuilding.html?ref=nyregion \&_r=0.
} 
high deployable wall, and the NYU Langone Medical Center and the New York and New Jersey Port Authority Buildings have also invested in temporary walls. ${ }^{67}$

\section{B. Implications for Further Replication}

Flood duration is a critical consideration in choosing the right flood control structure for a specific community. The longer the wall will be in contact with the floodwaters, the more potential there is for seepage and a need for backfill. ${ }^{68}$ Gravity floodwalls are most appropriate for areas needing only low-level protection. ${ }^{69}$

Agency and community planning is an essential part of adaptation measures. For example, floodwalls may only protect the low side of a building because they must tie into high ground. "When a building is protected by a floodwall, underground utilities that serve the building and run under the floodwall must be considered so the utilities do not become conduits that allow floodwaters to pass through or under the floodwall and into the building." ${ }^{70}$ When emergency planning, local governments can consider making it mandatory for any redevelopment in urban areas to have flood control structures in place.

In planning to use temporary barriers, the barrier must be the appropriate size for the site. It is also important to train emergency personnel and conduct drills so they are knowledgeable about how to deploy the barriers. An effective monitoring system is essential when using temporary floodgates because authorities need enough time to deploy the temporary barrier. Proper storage of the barriers and cleaning them after use will ensure their effectiveness for future events. ${ }^{71}$ These temporary barriers are most effective for river floodwaters and not for coastal floods; there has not been enough data about whether

\footnotetext{
${ }^{67}$ Id.; Heather Holland, NYU Langone Medical Center Builds Flood Wall-Shielded Emergency Room, DNAINFO N.Y. (Oct. 24, 2013), available at http://www.dnainfo.com/new-york/20131024/kips-bay/nyu-langone-medical-center-builds-floodwall-shielded-emergency-room; Press Release, "Port Authority of N.Y. \& N.J: "Port Authority Continues Aggressive Efforts to Rebuild Facilities Following Superstorm Sandy and to Prepare for Upcoming Hurricane Season" (May 29, 2013), available at http://www.panynj.gov/press-room/press-item.cfm?headLine_id=1794.

${ }^{68}$ See U.S. Fed. EMERgEnCy Mgmt. Agency, supra note 55.

${ }^{69}$ See id.

${ }^{70}$ See id.

${ }^{71}$ See id.
} 
saltwater hinders their performance. ${ }^{72}$ Additionally, temporary walls that fill with water may float instead of protect in denser saltwater. ${ }^{73}$

All flood control measures require consultations with engineers to determine the correct location and method of installation, and also to assess that the structure will provide adequate protection. This is essential because once the barriers are breached; they provide no protection. As an additional benefit, tidal gates can also restore the hydrogeology of interior wetlands while preventing saltwater intrusion. ${ }^{74}$

A drawback to permanent floodwalls is that they are very expensive and require massive amounts of material to build and create, especially if the height needed is significant. ${ }^{75}$ An aesthetic drawback to water control structures is that they may completely surround a structure.

\footnotetext{
${ }^{72}$ See id.

${ }^{73}$ See id.

${ }^{74}$ See id.

${ }^{75}$ See id.
} 


\section{Case 4: Using Citizen Monitoring as an Early Warning System to Minimize Damage from Storms}

Monitoring programs are an easy and effective way to minimize damage from future storms by monitoring conditions and using early warning systems. Citizen monitoring programs can be used to monitor water levels, water quality, sediment dynamics, storm patterns, wave strength, and erosion. Citizens who live on the shoreline are best situated to conduct monitoring during minor storms, because they usually will be present to observe a variety of weather conditions and patterns.

\section{A. How does Citizens Monitoring Work?}

Citizen monitoring programs allow citizens to monitor sea level rise and weather conditions when they are provided with the necessary equipment and training. The programs set up a system for data collection and results are submitted to a research program or government agency. Allowing citizens to monitor shoreline changes and weather conditions saves considerable cost because government agencies or academic institutions do not have to repeatedly travel to the shoreline. Additionally, the data collected provides a more comprehensive picture about weather patterns and shoreline alteration. The collected data can be shared with neighboring communities and with the state for use in local emergency, economic, and tourism planning. Sharing data prevents the duplication of efforts, saving time and valuable municipal resources.

In the United States, government agencies like the Environmental Protection Agency ("EPA"), and non-profit resource-protection agencies, ${ }^{76}$ have recognized the value of citizen monitoring programs. The EPA has Citizen Science Grants that provide citizens with smart phones and basic surveillance equipment to monitor water pollution and air quality. ${ }^{77}$ The EPA provides these individuals with training and educational brochures to distribute to other citizens in their community. The trained citizens periodically hold local town hall meetings to discuss their findings with the public and with the EPA. These forums act as question-and-

\footnotetext{
${ }^{76}$ New York-New Jersey Harbor \& Estuary Program, Citizen Science, http://www.harborestuary.org/citizenscience.htm (last visited June 30, 2014); RIVERKEEPER, Citizen Science Water Quality Monitoring Workshops, http://www.riverkeeper.org/news-events/events/other-events/citizen-science-workshop-1309/ (last visited June 30, 2014); UNIVERSITY OF RHODE ISLAND, Watershed Watch, http://www.uri.edu/ce/wq/ww/ (last visited June 30, 2014).

${ }^{77}$ EPA, Citizen Science Grants, http://epa.gov/citizenscience/ (last visited June 30, 2014) (discussing citizen air monitoring programs in Newark, New Jersey and in Tonawanda and the Bronx, New York).
} 
answer sessions for the public, while also informing the municipality and state officials about the current status and challenges. In the United States, coastal states like Maine have volunteer citizens monitoring for coastline erosion. ${ }^{78}$ Maryland incorporates citizens monitoring with training for coastal property owners to teach them how to implement shoreline erosion control practices. ${ }^{79}$

In Nicaragua, the CAFENICA Meteorological Station at Miguel Angel Ortez uses data provided by coffee farmers to monitor weather patterns. ${ }^{80}$ This data is used for strategic public planning and agricultural planning. The farmers are also trained in adaptation measures to help deal with anticipated droughts and dry seasons. ${ }^{81}$ In Kenya, a Michimikuru case study was used to train students to monitor conditions on the rivers. ${ }^{82}$ Five riverbank scouts were trained and certified on water and soil conservation. ${ }^{83}$ In Jakarta, citizen monitoring is being used to develop flood maps and create an early warning flood detection system. $^{84}$

\section{B. Implications for Further Replication}

Citizen monitoring programs are ideally replicable in shoreline areas inhabited by a local population to minimize the need to travel to the coast to conduct monitoring. Someone continuously residing on the shoreline is best situated to collect the data. Additionally,

\footnotetext{
${ }^{78}$ NOAA Office of OCEAn ANd CoAstal Resource MANAgEment, Support Research, Monitoring, and Decision Support Tools, http://coastalmanagement.noaa.gov/initiatives/shoreline_ppr_research.html\#1 (last visited June 30, 2014). Maine is using citizens to conduct monthly beach profiles to better understand seasonal erosion rates. Teams measure beach elevation, collect sediment samples, take pictures of the beach to document erosion, and report their data to geologists at the University of Maine and the Maine Geological Survey. See State of Maine, Beach Profiling Project, http://www.geology.um.maine.edu/beach/ (last visited June 30, 2014).

${ }^{79}$ NOAA, Education and Outreach Campaigns: Maryland's Shore Erosion Control Technical Assistance Program, http://coastalmanagement.noaa.gov/initiatives/shoreline_ppr_edu.html (last visited June 30, 2014); MARYLAND DEPARTMENT of Natural Resources, Chesapeake and Coastal Service, DNR Mobil Restoration Map, http://www.dnr.state.md.us/ccs/restoration.asp (last visited June 30, 2014); MARYLAND DEPARTMENT OF NATURAL ReSOURCES, Mobil Restoration Project Input Form and Mobil App, About, http://www.mddnr.org (last visited June 30, 2014).

${ }^{80}$ CAfÉ DireCt, Adaptation for Smallholders to Climate Change- How Nicaraguan Coffee Farmers Adapt to Climate Change- the PRODECOOP Case Study, http://www.adapcc.org/en/nicaragua.htm (last visited June 30, 2014) (case study, operating plan, and presentations available online).

${ }^{81} I d$. Farmers are trained in adaptation measures like how to manage stormwater by installing irrigation ditches to prevent landslides, using rainwater reservoirs, and storing water to be used in an installed pump for the community fountain. See Id.

${ }^{82}$ CAFÉ DiReCt, Pilot Groups- Kenya, http://www.adapcc.org/en/kenya.htm (last visited June 30, 2014); CAFÉ DiRECT, Michimikuru Tea Growers, http://producersfoundation.org/projects/michimikuru-tea-growers/ (last visited June 30, 2014).

${ }^{83}$ See CAFÉ DIRECT, Michimikuru Tea Growers, supra note 77.

${ }^{84}$ ASIAN DisASTER PREPAREDNESS CENTER, Flood Preparedness Initiatives of High-risk Communities of Jakarta 4-7 (2010), available at http://www.adpc.net/igo/category/ID226/doc/2013-c28Jbn-ADPC-Safer_Cities_27.pdf.
} 
citizens living in vulnerable coastal communities have a high interest in preparing their communities and protecting their property.

When implementing a citizen's monitoring program, it is necessary to have some distributable technology, like tidal gauges, thermistors, dynamometers, and turbidity tubes, that can be provided by a local government, a non-profit agency, or a university. ${ }^{85}$ These devices help citizens measure sea level rise, water quality, wave force, and water temperature. The issuers of the equipment must initially train citizens on their use and how to accurately collect the data. Those instruments will also require occasional maintenance and calibration, which can be done by an appointed lead citizen, the municipality, or a local university. Initially getting members of the public to volunteer to collect data can be difficult, so the preliminary organization of the program can be time-consuming. It is also necessary to have a location available to host monthly or quarterly town hall meetings so data can be presented.

All monitoring should be coordinated by a municipal or state agency, or by an academic institution. This coordination will assure a uniform method of data submission, organization, and publication. The data should be made publically available. Its use should help to aid developers and governments in conducting coastal vulnerability and risk assessments on future development projects. ${ }^{86}$ Ideally, the results of citizen monitoring should be incorporated into a database or online tool that neighboring municipalities and the state can access. Online entry forms, like the one for the Maine Beach Profiling Project, ${ }^{87}$ allow volunteers to input their data online to cut down on paperwork and faster transmission. ${ }^{88}$ It is important to note that data collected may be site-specific and not transferrable to neighboring communities.

\footnotetext{
${ }^{85}$ For an example of items to take under consideration when implementing a citizen monitoring program, see Ellin R., Spiegler, et. al, North Carolina Sentinel Site Cooperative: Report on the Sea-Level Rise Research and Monitoring Coordination Workshop at 36-38, 42-44 (NOAA Technical Memorandum NMFS-SEFSC650, 2013), available at http://oceanservice.noaa.gov/sentinelsites/pdf/NC_SSC_SLR_Research_Coordination_Wkshop.pdf. ${ }^{86}$ Caribbean Community Climate Change Center, Caribbean Adaptation to Climate Change Project ("CPACC"), $\mathrm{http} / / / \mathrm{www}$.caribbeanclimate.bz/closed-projects/1997-2001-caribbean-planning-for-adaptation-to-climate-change-projectcpacc.html (last visited June 30, 2014) (CPACC is a database designed to foster sustainable development in the Caribbean through making data available to developers, government, and the community on which adaptation measures will best protect the development and how to implement these measures).

${ }^{87}$ See STATE of MAINE, supra note 75.

${ }^{88}$ NOAA OfFice of OCEAn AND COASTAL Resource MANAGEMENT, supra note 62; see also StATE Of Maine, supra note 75.
} 


\section{Case 5: Green Infrastructure to Manage Gray Water}

Gray Water is storm water, regular rainwater and melted snow that runs off streets, lawns, and other urban sites. It can be used to supply all non-drinking water needs; in some countries it is widely used for agriculture. In Israel all buildings are required to have rainwater collectors on their roofs for use as drinking water. However, since it can pick up and transport chemicals, nutrients, sediment or other pollutants, and debris during heavy rain and snowmelt events, it can adversely affect water quality in the receiving water bodies. With the trend of urbanization and high frequency of storm weather in the context of climate change, Gray Water management has captured people's attention.

Traditional Gray Water management design has been focused on collecting Gray Water in piped networks and transporting it off site as quickly as possible, either directly to a stream or river, to a large Gray Water management facility (basin), or to a combined sewer system flowing to a wastewater treatment plant. ${ }^{89}$ Besides these concrete facilities (also called "Gray infrastructures"), a new type of method named green infrastructures that can address the concern of Gray Water runoff has been promoted in many cities in the United States. The project of Greenseams implemented by the City of Milwaukee, Wisconsin is a good example.

\section{A. How Does The Greenseams project Work?}

The Greenseams project was initiated in 2001. A "Greenseam," used by the City of Milwaukee, defines Greenseams lands as linkages throughout the utility service area watersheds that collectively work in sync to manage large amounts of water. After the Metropolitan Milwaukee Sewerage District ("MMSD") acquired all such lands "through voluntary sales and protected [them] with a permanent conservation easement.. Program staff "identified properties containing water-absorbing (hydric) soils and pinpointed them as priorities due to the amount of water they could hold." 90 These properties have an estimated 1.3 billion gallon storage capacity. ${ }^{91}$

\footnotetext{
${ }^{89}$ U.S. EPA, Stormwater Management, http://www.epa.gov/greeningepa/stormwater/ (last visted June 13, 2014).

${ }^{90}$ Jessica Hrobar, Innovative Program Connects Wastewater Utilities and Nature, Water World, http://www.waterworld.com/articles/uwm/articles/print/volume-4/issue-4/features/innovative-program-connects-wastewaterutilities-and-nature.html (last visited June 14, 2014).

${ }^{91}$ Supra SECTION \# .
} 
Utilizing plants is another important element of the program. Trees can break up raindrops and slow rainfall down before hitting the ground. Also, the deep and long roots of trees can hold water as well as decelerate erosion along stream banks. Nearly 100,000 trees have been planted under this project. ${ }^{92}$ These trees are all planted in a way that can maximize their storage function.

Besides the technical portion, the Greenseams program favors local communities' participation. The first requirement for this community involvement is that, since local land owners possess most of target properties of the project, it is crucial to reach out and establish a partnership with them. Next, contribution from local citizens helps to educate local communities and teach the value of the Greenseams project.

In the beginning, the project was not an immediate success. Local municipalities and landowners had a hard time understanding why a sewerage district would be buying land for preservation purposes, and furthermore, what the district would do with the property acquired. ${ }^{93}$ In order to penetrate local communities, it took several years to educate the public about why sewer district was implementing the Greenseams Program and what the long term vision was. $^{94}$

Currently, the Greenseams project covers more than 2,600 acres of land. ${ }^{95}$ After thirteen years of being in place, the program serves as a model in many cities in the United States on Gray Water management.

\section{B. Implications for Further Replication}

There are some common barriers to introducing green infrastructure into Gray Water management, such as limited land and technical support, barriers in codes and rules, and

\footnotetext{
92 MMSD, Greenseams, http://www.mmsd.com/en/floodmanagement/Greenseams.aspx (last visited June 14, 2014).

${ }^{93}$ Maragaret Buranen, Milwaukee Goes Green and Gray for Stormwater Management, http://www.stormh2o.com/SW/Articles/Milwaukee_Goes_Green_and_Gray_for_Stormwater_Manag_16762.aspx (last visited June 14, 2014).

${ }^{94}$ Supra SECTION \#.

${ }^{95}$ See MMSD at X.
} 
funding. ${ }^{96}$ Greenseams has been able to minimize these impacts, which could imply further replication in developing countries.

\section{How to Choose A Location?}

Greenseams is concentrating on projects in the most urban areas within four local major watersheds, where most suburban growth is expected. ${ }^{97}$ Also, these locations contain hydric soil and water-absorbing vegetation. ${ }^{98}$ The core idea is to maximize the value of green infrastructure. Suburban areas in developed or developing countries sometimes are those that have insufficient public facilities to deal with Gray Water. Instead of clearing the land to build traditional Gray Water treatment facilities, Green infrastructure made full use of the existing natural resources. ${ }^{99}$ For developing countries, it is relatively easy to pick up candidate locations that fit the above standards.

\section{How to Obtain Land and Funding}

In Milwaukee, all land was acquired through voluntary sales and protected with a permanent conservation easement. The project staff consistently broadened property sources by holding open house meetings, mailing out packets of information to addresses from a GIS database, and personally meeting with prospective sellers who were curious about the program. ${ }^{100}$ With regard to funding, about half the grants have come from a state program that facilitates cooperation between local governments and private non-profit organizations. The other half of the funding has come from the U.S. Fish \& Wildlife Service, other state programs, and local sources. ${ }^{101}$

\footnotetext{
${ }^{96}$ See Sarah A. Hammitt, Toward Sustainable Stormwater Management: Overcoming Barriers to Green Infrastructure, 1922 (2010), available at http://stuff.mit.edu/afs/athena/dept/cron/project/urbansustainability/Stormwater_Sarah\%20Madden/Shammitt_thesis_final.pdf. See also Oregon Environmental Council, Chapter 4: Barriers to Overcome, http://www.oeconline.org/our-work/water/stormwater/stormwater\%20report/barriers (last visited June 14, 2014).

${ }^{97}$ See Milwaukee Goes Green and Gray for Stormwater Management at X.

${ }^{98}$ See Innovative Program Connects Wastewater Utilities and Nature at X.

${ }^{99}$ Regarding the cost-benefit analysis between Gray and green infrastructure, see U.S. EPA, Water: Green Infrastructure Cost-Benefit Resources, http://water.epa.gov/infrastructure/greeninfrastructure/gi_costbenefits.cfm (last visited June 14, 2014).

${ }^{100}$ See Innovative Program Connects Wastewater Utilities and Nature at X.

${ }^{101}$ Supra at X.
} 
For developing countries, it is not a difficult challenge to acquire land compared to developed countries, while limited funding is a much greater barrier. Similar to the Greenseams project, cities in developing countries can utilize available grant funding to support to promote and maintain green infrastructure. Under some circumstances, cities or higher levels government should provide special funding for climate-related programs. 


\section{Case 6: Managed Retreat and Relocation}

During severe weather events, the permanent or devastating loss of coastal areas often prevents people from being able to return to their homes and communities. Planning the retreat and relocation of those affected by these events is essential to ensuring the wellbeing of a country's population.

\section{A. How Does Managed Retreat and Relocation Work?}

This adaptation mechanism could provide a sustainable way to adapt to climate change by removing people from harm's way. Managed retreat involves the retreat of a coastal population from areas identified as vulnerable or being threatened by adverse weather events. This departure can be to permanent resettlement locations or can be temporary during the adverse weather event and rebuilding period thereafter. However, depending on the level of destruction, even temporary displacement can have a long duration. Long-term resettlement may require relocation across national borders, which can be done by creating an agreement with neighboring countries that directly addresses this issue. ${ }^{102}$ The retreat can also be through a nationally run voluntary relocation program or a buyout program. ${ }^{103}$ For example, the Maldives promotes resettlement from outer islands to principal islands by establishing a "sovereign wealth fund to buy new land elsewhere as an insurance policy in the event of wholesale displacement, and to consolidate the population dispersed over 200 islands onto 10-15 islands." 104

\footnotetext{
${ }^{102}$ Dr. Shakeel Kazmi, Climate Change: Human Rights in the Times of Climate Displacement at 125, (Apr. 1, 2012) (S.J.D. dissertation, PACE UNIVERSITY SCHOOL OF LAW), available at http://digitalcommons.pace.edu/cgi/viewcontent.cgi?article=1013\&context=lawdissertations.

${ }^{103}$ In the United States, Harris County, Texas has formed a "voluntary home buyout" program to relocate households living in flood plains. See Harris County Flood ConTrol District, Voluntary Home Buyout, http://www.hcfcd.org/buyout.asp?flash=yes (last visited June 30, 2014). Vietnam has implemented a "Living with Floods" program to resettle 20,000 landless and poor households living in regularly flooded areas to nearby but less endangered areas. See Benoit Mayer, The International Legal Challenges of Climate-Induced Migration: Proposal for an International Legal Framework, 22 COLO. J. INT'L ENVTL. L. \& POL'Y (2011), available at http://www.colorado.edu/law/sites/default/files/Mayer\%20\%28Corrected\%29-S.pdf. Mozambique is promoting voluntary resettlement from floodplains to higher ground. See also Alex de Sherbinin, Government-led Displacement and Resettlement Due to Climate Change, COLUMBIA UNIV. CTR. FOR INT'L EARTH SCIENCE INFO. NETWORK (Planet Under Pressure Conference Mar. 28, 2012), available at http://www.planetunderpressure2012.net/abstracts/D3041307.pdf.

104 This fund is financed by diverting a portion of the country's tourist revenue to buying land in India, Sri Lanka, and Australia. Uma Kothari, Politicial Discourses of Climate Change and Migration: Resettlement Policies in the Maldives, 180
} 
Climate refugees are people who are forced from their homes due to the effects of climate change, including natural disasters and coastal flooding or sea level rise. ${ }^{105}$ Under the United Nations, this displaced population is not entitled to refugee status. ${ }^{106}$ There is no international fund that exists to support climate displacement refuges. ${ }^{107}$ This situation can have significant impacts on the rights of those relocating and can affect funding available to the countries receiving displaced communities. Right now, the term refugee is being heavily debated and a possible universal right to housing is being used as support for awarding climate refugees protection. ${ }^{108}$

\section{B. Implications for Further Replication}

Retreat can be done in four stages, starting with the planning process. It is important to plan the resettlement process and choose a dedicated government agency that will be vested with authority and resources to run the program. The program should have clearly stated goals and objectives for all stages of the process and a detailed plan to achieve them. These objectives should address issues like living standards for those resettled and establishing a fund for large scale displacement in the event that a major natural disaster displaces a large number of people.

The second stage is relocation planning, including evacuation plans to orderly move communities out of harm's way. To evacuate entire communities, evacuees are told to meet at a

\footnotetext{
GEOGRAPHICAL JOUNRAL 130, 135-36 (2014), available at http://onlinelibrary.wiley.com/store/10.1111/geoj.12032/asset/geoj12032.pdf?v=1\&t=hxfgpk1t\&s=6307bc8e0c6220d1b11a4 b5e 54c5e25fd69bac88. The Maldives also tries to entice migration to principal islands by increasing connectivity, transportation, and building accomodations on the main islands. Id. Alex de Sherbinin, Assessing Displacement and Resettlement Due to Climate Change Mitigation and Adaptation Projects, at 15, COLUMBIA UNIV. CTR. FOR INT'L EARTH SCIENCE INFO. NETWORK (IAIA Symposium on Climate Nov. 15-16, 2010), available at http://www.ciesin.columbia.edu/confluence/download/attachments/92799474/deSherbinin_IAIAsymposium_nov2010.pdf.

${ }^{105}$ See generally Michael B. Gerrard and Gregory E. Wannier, ThreATENED IsLAND NATIONS: LEGAL IMPLICATIONS OF Rising Seas and a Changing Climate (2013); National Geographic, Climate Refugee, http://education.nationalgeographic.com/education/encyclopedia/climate-refugee/?ar_a=1 (last visited June 30, 2014).

${ }^{106}$ Dr. Shakeel Kazmi, supra note 99 at 19-21; Jane McAdam, UNHCR, Climate Change Displacement and International Law: Complementary Protection Standards (2011), available at http://www.unhcr.org/4dff16e99.html (last visited June 30, 2014).

${ }^{107}$ Dr. Shakeel Kazmi, supra note 99 at 19.

${ }^{108}$ Id.; Silke Marie Christiansen, ENVIRONMENTAL REFUGEES: A LEGAL PERSPECTIVE, THE TERMINOLOGY DEBATE, 9 (2010), citing Richard Black, ENVIRONMENTAL REFUGEES: MYTH OR REALITY? 2 (2001).
} 
dedicated location, usually a school or a church, where buses are used for transportation. ${ }^{109}$ As a model for relocating communities, planners can look to the methods used by countries resettling communities to accomplish major dam-building projects. ${ }^{110}$ Evacuation planning also includes identifying the location of where people can resettle. This location must be planned in advance, in coordination with other countries if extraterritorial resettlement is contemplated, or through purchasing or preparing land in a different location for resettlement locally.

The third step involves initiating economic development in the areas identified for permanent relocation to which refugees are to be resettled. When planning for relocation of people inside the same country, there are important considerations that must be taken to prevent deterioration of the resettlement areas and impacts on the rest of the country. The initial drop in living standards of those relocated following relocation should also be addressed in this plan and must focus on preventing the creation of slums and over-crowding. ${ }^{111}$ This third step also includes planning with international relief agencies for temporary food, medical care and shelter. Inn the longer term plans need to be made for employment opportunities and adequate access to grocery stores, markets, healthcare and education facilities. Additionally, this step should focus on community formation and activities to improve living standards for those resettled. Community formation includes things like places of worship with religious compatibility, community centers, and the creation of social groups.

Finally, after each weather event requiring retreat and temporary or permanent displacement, an after-action review must be conducted to assess the procedures in place and pinpoint where

\footnotetext{
${ }^{109}$ U.S. Fed. EMERGENCy MGMt. AGENCy, Emergency Declarations and Sheltering Evacuees, http://www.fema.gov/emergency-declarations-sheltering-evacuees (last visited June 30, 2014).

${ }^{110}$ Dam Projects with major resettlement components include Mali's Manantali Dam, see Peter Bosshard, A Case Study on the Manantali Dam Project, INTERNATIONAL RIVERS (Mar. 1, 1999), available at

http://www.internationalrivers.org/resources/a-case-study-on-the-manantali-dam-project-mali-mauritania-senegal-2011, Egypt's Aswan Dam, see Penn. State Univ., Problems with the Aswan Dam, https://courseware.eeducation.psu.edu/courses/earth105new/content/lesson06/04.html (last visited June 30, 2014), Costa Rica's Arenal Dam, see United Nations Environment Programme: Dams And Development Project, Costa Rican Expropriation Law and Inter-American Development Bank Requirements for Development Projects: The Arenal Dam, Development Submission, http://www.unep.org/dams/documents/ell.asp?story_id=95 (last visited June 30, 2014), and Sri Lanka's Pimburetewa Dam, see Thayer Scudder, A Comparative Survey of Dam-induced Resettlement in 50 Cases, CAL. TECH. (2005), available at http://www.hss.caltech.edu/ tzs/50\%20Dam\%20Survey.pdf.

${ }^{111}$ Dr. Shakeel Kazmi, supra note 99 at 19.
} 
improvements can be made. Those improvements should be implemented to create a sustainable redevelopment process.

There are drawbacks to managed retreat. First, and most apparently, it can be politically difficult to implement. People do not want to leave their homes and communities, and this can cause a lack of participation in voluntary resettlement. And a location receiving the refugees also will need to plan for their provisioning and treatment. Next, retreat and relocation require a reliable monitoring system to remove people safely before inclement weather. This means having early warning and detection methods available, such as installing flow regulators along rivers. ${ }^{112}$ After the permanent relocation, it is best where possible for the receiving country to provide in advance for land, facilities and support to accommodate the refugees. ${ }^{113}$

These measures create strain on the existing infrastructure in the receiving location that must be assessed and addressed. Managed retreat to domestic areas commonly involves moving populations to current internal cities. This exerts pressure on the city's infrastructure, and economy, and also creates the potential for overcrowding. This may lead a country to plan for permanent relocation outside of the country. This kind of settlement plan requires agreements with the receiving countries and provision for multi-national cooperation and funding. When identifying countries with which to collaborate, it is important to try to choose countries that have the same or similar language, education systems for children, religion or places of worship that are available, and job

\footnotetext{
112 The Bangladesh government has installed flow meters along rivers. See Shardul Agrawala, et al., Development And Climate Change In Bangladesh: The Sundarbans, Adaptation Options Available For Management Of Coastal Flooding 35, ORGANIZATION FOR ECONOMIC COOPERATION AND DEVELOPMENT (2003), available at http://www.oecd.org/dataoecd/46/55/21055658.pdf.

${ }^{113}$ In 2008, Maldives' President Nasheed announced plans to create a fund from revenue generated by tourism, to be used to acquire land to relocate its population in countries such as India and Sri Lanka. Dr. Shakeel Kazmi, supra note 74 at 161. The right to housing in the Maldives in threatened by a scarcity of land and is still looking to permanently relocate victims of the 2004 Tsunami. United Nations News Centre, Maldives: Climate Change Threatens Right to Housing, Says UN Expert (Feb. 26, 2009), available at http://www.un.org/apps/news/story.asp?NewsID=30026\&Cr=housing\&Cr1=climate\#.U7X-814_594. With the help of federal funding, the State of New Jersey has acquired homes in flood-prone areas to prevent resettlement. Press Release, New Jersey Dept. Envt'l Prot., Christie Administration Announces \$26.3 Million in Federal Aid for Post-Sandy Buyouts of 89 Residential Properties in Woodbridge, (Feb. 6, 2014), available at http://www.nj.gov/dep/newsrel/2014/14_0009.htm.
} 
opportunities. ${ }^{114}$ Furthermore, some countries have their own internal policies for climate refugees and an application process that citizens may need help in fulfilling. ${ }^{115}$

\section{ENERGY CASE STUDIES}

\section{Case 7: Renewable Energy to Provide and Secure Power to Communities During Severe Weather Events}

Renewable energy can provide a way to secure a power supply for communities in areas vulnerable to power outages or that are dependent on power supplied from a far distance. Many renewable resources with a micro grid can be used to supply power during major storms. This case studies focuses specifically on using micro hydropower for providing energy to communities immediately after severe events, obviating the need for grid electricity ${ }^{116}$

\section{How does Micro Hydropower Work?}

Micro hydropower consists of small turbines and a generator to produce electricity. The turbines only require a small flow of water that can be provided by a natural source. The amount of flow required, approximately two gallons per minute, or water with a small elevation drop ${ }^{117}$ in its course of flow, will generate sufficient electricity to run a micro hydropower unit. ${ }^{118}$ This running

\footnotetext{
${ }^{114}$ Dr. Shakeel Kazmi, supra note 99 at 51, 140.

${ }^{115}$ New Zealand accepts climate refugees but has requirements regarding age and career abilities for applicants applying for refuge. Immigration New Zealand, Knowledge Base,

http://www.dol.govt.nz/immigration/knowledgebase/item/1129 (last visited June 30, 2014); Dr. Shakeel Kazmi, supra note 73 at 125 .

${ }^{116}$ This method would have been ideally utilized after Superstorm Sandy in New York where parts of the Rockaway community, totaling 100,000 people, were without power for over a month after the storm. NEW YORK CiTY, Hurricane Sandy After Action Report, May 2013, available at http://www.nyc.gov/html/recovery/downloads/pdf/sandy_aar_5.2.13.pdf. After the storm, many people did not have a way to call for help. A power source to charge cell phones would have connected the devastated community with emergency responders, making rescue and medical aid operations easier. The New York City Hurricane Sandy After Action Report specifically lists better coordination of relief to affected areas and a better capacity to deal with loss of power as recommendations on how the city can improve emergency preparedness. Id. Similarly, these units could have been utilized during Hurricane Irene in Vermont where roads were washed out and emergency crews could not access the town of Wilmington, calling it "cut-off." CNN, Irene Leaves Damaging and Deadly Floods, Rushing Waters, Aug. 28, 2011, http://www.cnn.com/2011/US/08/28/tropical.weather/ (last visited June 30, 2014).

${ }^{117}$ A small drop in elevation that is approximately two feet is sufficient to harness energy. See PrACTICAL ACTION, supra note 114.

${ }^{118}$ ApPalachian State University, Fact Sheet: Microhydro (2007), available at

http://appropriatetec.appstate.edu/sites/appropriatetec.appstate.edu/files/microhydro_factsheet6.pdf; see PRACTICAL ACTION, supra note 114. Additionally, this "run of river system" has little impact on the environment because water passing through generator goes back into the stream and it is utilizing a renewable resource. See PracticAl Action, supra note 114.
} 
water source could be a Gray Water runoff ditch, which could handle the requisite flow after a severe precipitation event. Additionally, multiple Gray Water runoff ditches could be constructed to slow the flow of just one ditch, and additional units can be installed, maximizing the amount of power that can be captured.

This electricity can be delivered from the power unit to locations up to a mile away. These units can also be connected to power networks or grids, but more frequently they are used as standalone power for remote areas. The harnessed power is stored in portable rechargeable batteries and supplied by transporting these batteries to communities, which minimizes expensive connection costs. ${ }^{119}$ The output from the turbine shaft can also directly be used for mechanical power. ${ }^{120}$

Operation and maintenance of these systems can be carried out by trained local craftspeople. Since local citizens are trained and the units are small, micro hydropower is relatively inexpensive to operate. Areas of low income can also be benefited, not only from power security and job creation, but also by improved lighting, communications, refrigeration to store medicines and food and economic stimulation. ${ }^{121}$

In mountainous regions of Peru and Kenya, power is generated from micro hydropower units with turbines in mountain, rivers, generating power from water flowing down a cliff after precipitation events. ${ }^{122}$ Sri Lanka has 200 mini development projects to take advantage of rivers that form during flood season. ${ }^{123}$ Other countries are looking into installing micro hydropower units to secure power to communities. ${ }^{124}$

\footnotetext{
${ }^{119}$ Appalachian State University, supra note 116; Practical ACtion, supra note 114.

${ }^{120}$ Practical Action, supra note 114.

${ }^{121} I d$.

${ }^{122} I d$.

${ }^{123}$ Hydro ReVIEw, Sri Lanka Micro Hydro Rehabilitation Projects Receive Boost from new ADB Loan, Jan. 18, 2013, available at http://www.hydroworld.com/articles/2013/january/sri-lanka-micro-hydro-rehabilitation-projectsreceive-boost-from.html.
}

\footnotetext{
${ }^{124}$ Russia has a growing interest in using micro hydropower in the northern Caucasus. RUSHYDRO Investment Program is funding these projects, including the Barsuchkovky and Stravopol developments. See WATER, POWER \& DAM CONSTRUCTION, RusHydro's Small Hydro Projects Selected at RES Auction (June 19, 2014), available at http://www.waterpowermagazine.com/news/newsrushydros-small-hydro-projects-selected-at-res-auction-4297728. In Assam, India, 149 small hydropower projects are being planned. HydroWorld.com, India's Assam State Planning Massive Small Hydro Expansion, SMALl HYdro (July 1, 2012), available at http://www.hydroworld.com/articles/print/volume-20/issue4/departments/small-hydro.html. The Philippines is investigating installing mini hydropower sites in rural areas. Liu, H., Masera, D. \& Esser, L., eds., World Small Hydropower Development Report 2013 Executive Summary 14-15, United Nations Industrial Development Organization; International Center on Small Hydro Power, available at http://www.smallhydroworld.org/fileadmin/user_upload/pdf/WSHPDR_2013_Executive_Summary.pdf.
} 


\section{B. Implications for Further Replication}

Provision must be made to charge batteries for the system, usually thru solar eneregy or wind turbines. .A training program must be established for the workers who will be operating and maintaining the system. ${ }^{125}$ Community members must be willing to be trained and take on full responsibility for operating and maintaining the power system. A fee generally is charged for using the electricity.The local community can employ craftspeople to maintain the systems. The available water sources and sources that appear during precipitation events must be assessed to determine the best location for the micro hydropower unit.

The units are typically initially funded by a non-profit or emergency management government agency. Some communities decide to utilize the power more frequently than just during storm events, and end up charging users for this during regular non-severe conditions. This generates income and revenue for the community to fund the operation and maintenance of the equipment.

A region with hills or varying topography is ideally suited for this adaptation method. Additionally, the technology is still developing for further improvements in equipment designs. Countries can communicate with one of the organizations actively involved in helping to set up micro hydropower units to receive more information. ${ }^{126}$

\footnotetext{
${ }^{125}$ An added benefit of preparing a community with micro hydropower is the creation of jobs.

${ }^{126}$ United Nations Industrial Development Program (“UNDP”), Small Hydropower, http://www.unido.org/en/whatwe-do/environment/energy-access-for-productive-uses/renewable-energy/focus-areas/small-hydro-power.html (last visited June 30, 2014). Practical Action is a non-profit organization that partners with UNDP to implement micro hydropower solutions in Peru, Sri Lanka, Kenya, and Zimbabwe. See PracticAl ACTION, http://practicalaction.org/micro-hydro-power (last visited June 30, 2014).
} 


\section{Case 8: Rooftop Solar and Distribution Generation}

Growth in distributed generation indicates the beginning of a revolution in the way that electricity is generated and transmitted in the world. The current dominant production and distribution model consists of large, centralized power plants delivering electricity across a large area grid to 'consumers. In contrast, rooftop solar photovoltaic (PV) systems generate power to be utilized on-site or nearby-power travels a much shorter distance. Although it is not necessarily enabling a home or business to be totally energy self-sufficient, having solar panels still increases the degree of customer independence and energy security substantially.

With the rapidly decreasing cost of solar power technology, rooftop solar provides widely affordable clean energy. ${ }^{127}$ In order to seize this favorable condition, some large solar projects are expanding in developing nations, ${ }^{128}$ The renewable solution can be developed on ordinary rooftops on a community basis rather than with large solar fields. The example of the extensive rooftop solar programs in Austin, Texas demonstrates their benefits.

\section{A. The St. David's Episcopal Church Project}

St. David's Episcopal Church (the Church), located in the heart of downtown Austin, worked with a local utility company and a solar-focused engineering company and created a rooftop solar project on an "unprecedented scale." 29 The Church project's uniqueness provides an example of how to integrate community rooftop solar into an existing utility grid network.

Accelerating adoption of custormer-installed photovoltaic solar panels is and eroding utility sales and revenues. ${ }^{130}$ Therefore, some American electric utilities see this solar growth

\footnotetext{
${ }^{127}$ According to a UNEP-backed report, the average price of crystalline silicon solar modules fell by $30 \%$ or more in 2012 in the solar PV industry. See REN 21, Renewable Status 2013:Global Status Report, 47(2013), available at http://www.unep.org/pdf/GSR2013.pdf. Another report estimates that the solar PV manufactures are expected to fall another $6 \%$ during 2014, continuing the downward trend set in places since 2008, bringing the overall cost to a record low of $\$ 0.20$ per watt. See Joshua S. Hill, Solar PV Production Costs to Drop In 2014, Clean Technica, http://cleantechnica.com/2013/11/22/solar-pv-production-costs-drop-2014/ (last visited June 14, 2014).

${ }^{128}$ See Zachary Shahan, Giant Solar Power Projects Now Hitting Developing World, Abb-Conversations, April 7, 2014, http://www.abb-conversations.com/2014/04/giant-solar-power-projects-now-hitting-developing-world/ (last visited June 14, 2014).

${ }^{129}$ See Marita Mirzatuny, Austin Unveils Texas-Sized Rooftop Solar Array to Power Downtwon Church, Environmental Defense Fund, Mar. 4, 2014, http://blogs.edf.org/texascleanairmatters/2014/03/04/austin-unveils-texas-sized-rooftop-solararray-to-power-downtown-church/ (last visited June 14, 2014).

${ }^{130}$ Giles Parkinson, Rooftop Solar: Does It Really Need the Grid?, Renew Economy, Apr. 23, 2014, http://reneweconomy.com.au/2014/rooftop-solar-does-it-really-need-the-grid-10987 (last visited June 14, 2014).
} 
as a threat to their businesses, prompting them to cut back on incentives for solar power. However, Austin Energy, the partner utility company in this project, embraces the rooftop solar trend by introducing a new way to calculate the utility bill once its customers go solar. Customers that choose solar in Austin Energy's service area continue to pay a monthly energy bill based on how many kilowatt-hours of electricity they consume. Yet those customers are given a credit called "value of solar tariff" for each kilowatt-hour their solar systems generate. That credit is subtracted off the customers' total monthly electricity bill. This credit price is calculated based on "expected fuel savings, offset power plant construction, transmission and distribution savings, and environmental benefits". ${ }^{131}$ With this new price mechanism, the conflict between rooftop solar installation and utility companies is largely relieved.

Another challenge for the project was how to connect the solar array to the grid. For years, the design of Austin Energy's downtown distribution system limited the size of rooftop solar to a maximum of 20 kilowatts-less than one seventh the size of St. David's array. ${ }^{132}$ This technical barrier was solved by working closely with Meridian Solar, an engineer company as well as the Church project developer.

With the implementation of the project, the Church successfully reduced its electricity bill and had enough saved money to donate to charity work.

\section{B. Implications for Further Replication}

Nearly 1.3 billion people do not have access to electricity and more than 2.6 billion people still rely on the traditional use of biomass for cooking. Across developing countries, the average electrification rate is $77 \%$, while it increased to around $91 \%$ in urban areas with the trend of urbanization. ${ }^{133}$ The situation of energy access in developing countries has two characteristics: (1) A large amount of population live without modern energy access, and; (2) Demand for electricity in urban areas is expected to continue to increase with rapid urban

\footnotetext{
${ }^{131}$ See Austin Unveils Texas-Sized Rooftop Solar Array to Power Downtwon Church at X.

${ }^{132}$ Supra at $X$.

${ }^{133}$ See International Energy Agency, Energy Access Database, http://www.worldenergyoutlook.org/resources/energydevelopment/energyaccessdatabase/ (last visited June 14, 2014).
} 
population growth, which will place an ever increasing strain on existing electrical production, generation, transmission, and distribution systems.

With many developing countries struggling to make utilities economically sustainable and meet increased energy demand, the time is right for governments to re-evaluate their energy strategies and begin to take advantage of the benefits that renewable distributed generation can provide. ${ }^{134}$

Nevertheless, for both developed and developing countries, this new paradigm energy system is facing p;otential conflict with traditional commercial electricity companies. It is crucial to understand how to ally with utility companies rather than exclude them from the blue-print at an early stage.

There were three key parties to the Austin Church project partnership: the utility company (Austin Energy), the private engineering company (Meridian Solar), and the Church. The Church, as a non-commercial entity, served as a coordinator and liaison to all parties to ensure project success. Similar entities like schools, hospitals, governments at local level can replicate the Church project with similar programs. These community entities have a similar strong social influence and can afford renewable system installation more easily compared to one single household.

With regard to the technical challenges, developing countries should start investing human capital and education in renewable distributed generation. In the Church project, the utility was very progressive and the technical developer was an engineering company with more than a decade of experience on renewable energy, which means understanding relevant technologies fully enabled it to solve the connection difficulty smoothly.

\footnotetext{
${ }^{134}$ Main benefits of renewable distributed generation can be viewed from two perspectives. For energy consumers, it can increase power supply quality with greater flexibility and lower costs. Particularly the advantage of flexibility is more obvious during storms and other extreme weather events. For the grid-side, renewable distributed generation can reduce cost and energy loss during transmission and distribution; also, its increased reliability has siting, planning and construction benefits. See U.S. Agency For International Development, Increasing Energy Access in Developing Countries: The Role of Distributed Generation, 13-18 (2004), available at http://www.bcse.org/files/Increasing_Energy_Access.pdf.
} 


\section{Case 9: Strengthening Powerline Transmission}

High winds and seasonal storms have increased in both frequency and intensity, which causes more frequent damage to electrical systems, especially overhead utility lines. ${ }^{135}$ One answer is to start replacing central station power production requiring lengthy and vulnerable transmission with distributed power production with minigrid distribution to customers as described above;

Where strengthening power transmission is essential, a country's power transmission system usually can be strengthened by replacing or updating the aging or failing electricity infrastructure.

Common strengthening strategies include: ${ }^{136}$ (1) Technology-based upgrades. Updating power lines through measures such as rebuilding transmission lines to increase capacity, underground cable replacement, and reconditioned circuitry. Some power companies have replaced aluminum transmission lines with composite materials to strengthen transmission lines and reduce sagging of the lines and (2) Management-based upgrades that provide better monitoring of transmission line conditions and anticipation and addressing of transmission vulnerabilties. Also, many utility companies have focused on existing crewtraining programs, which can provide an opportunity for staff respond to emergencies more quickly and with higher efficiency. Working with arborists to implement a vegetation management plan including properly trimmed tree limbs can be important to preventing outages from falling limbs.

\footnotetext{
${ }^{135}$ A new report shows that a tenfold increase in major power outages (those affecting more than 50,000 customer homes or businesses), between the mid-1980s and 2012 in the U.S. Some of the increase was driven by improved reporting. Yet even since 2003, after stricter reporting requirements were widely implemented, the average annual number of weather-related power outages doubled. Non-weather related outages also increased during that time, but weather caused 80 percent of all outages between 2003-2012. See Climate Central, Blackout: Extreme Weather, Climate Change and Power Outage, 3 (2014), available at http://assets.climatecentral.org/pdfs/PowerOutages.pdf . Also, the situation is similar at a global scale. Major grid failures have been doubled since 2000. See James McLinn, Major Power Outage in the US, and Around the World, 1 (2009), available at http://paris.utdallas.edu/IEEE-RS-ATR/document/2009/2009-06.pdf .

${ }^{136}$ See Richard J.Campbell, Weather-Related Power Outages and Electric System Resiliency, 8-13 (2012), available at http://www.fas.org/sgp/crs/misc/R42696.pdf.
} 


\section{A. How Do the Projects Work?}

Florida Power \& Light Company ("FPL"), as the largest electric utility in Florida and one of the largest rate-regulated utilities in the United States, expanded its investment in major upgrades to nearly 100 main power lines and other infrastructure to further strengthen its electric grid against severe weather. ${ }^{137}$ The shining point of this plan is to help communities within FPL's service territory recover more quickly from major storms and improve everyday reliability for its customers.

To achieve this goal, the plan is focused on upgrades to power lines and equipment serving essential community facilities - including hospitals, police and fire stations, 911 centers, water treatment plants, grocery stores, pharmacies and gas stations - that are crucial to people and businesses as they recover from damaging storms.

A program proposed for implementation in Indonesia, called West Kalimantan Power Grid Strengthening Project, aims to allow for power trading between two countries to import more adequate and secure power to the electricity grid. ${ }^{138}$

Large numbers of customers in West Kalimantan, Sumatera and the other outer islands of Indonesia do not have access to grid connected power supply. Their existing power generation, which heavily relies on traditional fuels, is facing extreme increases in electricity demand. Therefore, PLN, the state-owned power utility in Indonesia, plans to import hydropower generated electricity from neighboring Sarawak, Malaysia by building an $83 \mathrm{~km}$ $275 \mathrm{kV}$ transmission line from its Bengkayang substation to the border with Sarawak, Malaysia. On the Malaysian side, SESCO, the state owned power utility in Sarawak, will build about $42 \mathrm{~km} 275 \mathrm{kV}$ transmission line from Mambong substation to the border with West Kalimantan.

\footnotetext{
${ }^{137}$ See Florida Power \& Light Company, FPL Plans to Strengthen Record Number of Power Lines in 2014, FPL Newsroom http://newsroom.fpl.com/2014-02-24-FPL-plans-to-strengthen-record-number-of-power-lines-in-2014 (last visited June 14, 2014).

${ }^{138}$ See Asian Development Bank, West Kalimantan Power Grid Strengthening Project, http://www.adb.org/projects/41074013/details (last visited June 14, 2014).
} 


\section{Implications for Further Replication}

Although these two projects require substantial grant funding, they highlight some important messages regarding powerline-strengthening.

First, a powerline-strengthening plan should concentrate on essential community/public facilities. Since developing countries have limited funding resources, the priority plan should encompass infrastructure that has strong social influence as much as possible, which also resonates the idea of development of renewable distributed generation as stated in Case 8 .

Second, the plan must highlight regional cooperation. In the case of West Kalimantan Project, the hydro-resource is the main factor that stimulated the cooperation between two countries. 


\section{FOOD CASE STUDIES}

\section{Case 10: Grow Crops in A New Way}

Disproportionate rains and rising temperatures are affecting the abundance and distribution of harvested agricultural species, according to the fifth IPCC report. Although some benefits have been brought by climate change in some high-latitude regions, negative impacts of climate trends have been much more common than positive ones. ${ }^{139}$ Severe negative impacts on crops production such as wheat and maize is estimated for low latitude countries."

These changes in food system drivers give rise to changes in food security outcomes. Based on the Fifth Assessment Report of IPCC, the largest numbers of food insecure countries will be found in South Asia. ${ }^{141}$ Therefore, adaptation has significant meaning to low latitude developing countries in this area which heavily rely on agriculture in their domestic production.

Currently, food production is the most common entry point for adaptation. Two ways can increase agricultural resilience: (1)New crops grown in the same spot; and (2) New crops grown in new growing areas.

\section{-New crops grown in the same spot}

Due to water scarcity and other climatic changes, original crops that grow in one location may reduce their yield and even become hard to grow. Therefore, the first solution aims to take advantage of new agricultural technoliges to cope with the new weather patterns and to maintain a stable production yield by introducing different crops that can adapt to the climate.

According to a climate assessment report developed by the State of Connecticut, ${ }^{142}$ dairy farming is one of the top five industries in the state that will be most affected by climate

\footnotetext{
${ }^{139}$ See IPCC, The Fifth Assessment Report-Chapter 7. Food Security and Food Production Systems, 2 (2013), available at http://ipcc-wg2.gov/AR5/images/uploads/WGIIAR5-Chap7_FGDall.pdf.

${ }^{140}$ Supra, 3 and 6.

141 Supra, 5.

142 The top five most imperiled agricultural planning areas or features in Connecticut were maple syrup, dairy, warm weather produce, shellfish and apple and pear production. See Adaptation Subcommittee of Connecticut, The Impacts of Climate Change on Connecticut Agriculture, Infrastructure, Natiral Resources and Public Health, 4 (2010), available at http://www.ct.gov/deep/lib/deep/climatechange/impactsofclimatechange.pdf.
} 
change. This result is due to high daytime temperatures and absence of nighttime cooling,causing stress on cows and decreasing milk production. ${ }^{143}$ Yet this kind of weather is perfect for growing grapes. In this context, the government decided to promote the replacement of dairy farming with vineyards in affected areas.

\section{A. How Does the Project Work?}

Under the legal requirements at both state and federal level, for a bottle to be labeled as a Connecticut wine, producers must obtain a certain amount of grapes from state growers. ${ }^{144}$ Good ingredients determine the quality of wine. As a result, it was necessary to refine the quality of locally grown grapes.

The Connecticut government partnered with the Extension School of University of Connecticut to carry on research to provide training programs to new grape growers, in particular, those dairy farmers who facing declining dairy farming and were looking for new income resources. A Scaling Up Program for beginning farmers, funded by U.S. Department of Agriculture (USDA), offered a three-year outreach and training program for new and beginner vineyard farmers in Connecticut. ${ }^{145}$ Under this program, a group of experts will work closely with a number of beginning farmers over three years, helping them solve initial barriers as well as challenges. It is worth mentioning that the training program is not only about growing operations, but also includes farm planning management and conservation. ${ }^{146}$ But the Connecticut government does not stop there.

In order to enable its agricultural market consumption with grapes, Connecticut established the Connecticut Farm Wine Development Council, a volunteer council under administrative authority of the Connecticut Department of Agriculture, to promote local

\footnotetext{
${ }^{143}$ Supra, 14.

${ }^{144}$ The state law requires vineyards to use a minimum of $25 \%$ state grown grapes for their total wine production, and federal labeling laws are more strict having a requirement of $75 \%$ of grapes grown in the state for any bottle to be labeled as a state wine, with an even more stringent requirement of $95 \%$ of grapes grown on the particular vineyard site in order to include it on the label. See Jeremy L. Jelliffe, An Economic Analysis of Wine Grape Production in the State of Connecticut, 2 (2012), available at http://digitalcommons.uconn.edu/cgi/viewcontent.cgi?article=1393\&context=gs_theses.

${ }^{145}$ See UConn Extension, Scaling Up Program (2013), available at http://ipm.uconn.edu/documents/raw2/364/Scaling\%20Up\%20Program.pdf.

${ }^{146}$ Supra at X.
} 
wineries. All licensed farm wineries are eligible to participate in the council's activities. ${ }^{147}$ Two main responsibilities that the Wine Council has are marketing Connecticut-produced wine and advocating passage of supporting legislation. ${ }^{148}$

What the Wine Council does is crucial. On one hand, it paves the road to sell the grapes and adds more confidence to farmers (including beginning farmers) to shift their focus to new crops. Its policy and legislation campaigns also can provide more certainty to the growing of new crops.

With these efforts, the wine industry in Connecticut projects a steady growth rate of $3.9 \%$, which is higher than the national average. ${ }^{149}$

\section{B. Implications for Further Replication}

First, academic institutions bridge knowledge gaps by selecting suitable plants for location and training. In fact, a vast body of resources is available from all sorts of organizations for small farmers. Unfortunately, many of the small farmers and ranchers are unaware of how to utilize the information and opportunities. From the case above, it can be seen that the Scaling Up Program hosted by the University of Connecticut has played a key role in providing farmers with knowledge support.

Another similar Connecticut program, called Small Farmers' Outreach, created by the Lincoln University Cooperative Extension, aims to educate farmers by visiting their sites on an appointment basis and giving customized advice for free. ${ }^{150} \mathrm{With}$ the professional diagnosis, the owner usually can raise income and increase yield production.

Similar examples are happening in some developing countries already. It is significant to summarize the merits of this type of practice.

\footnotetext{
${ }^{147}$ Connecticut Department of Agriculture, Connecticut Farm Wine Development Council: Moving the Industry Forward, http://www.ct.gov/doag/cwp/view.asp?Q=532870\&A=1401 (last visited June 23, 2014).

${ }^{148}$ Supra.

${ }^{149}$ See An Economic Analysis of Wine Grape Production in the State of Connecticut, 1.

${ }^{150}$ See Lincoln University, Cooperative Extension, http://www.lincolnu.edu/web/cooperative-extension/cooperativeextension (last visited June 23, 2014).
} 
The importance of the Connecticut examples is highlighted in developing countries. In Zimbabwe, due to increasingly unpredictable weather driving up the price of maize meal, people in many regions started planting sweet potatoes during the rainy season, which could assist small-scale subsistence farmers to feed their family as well as sell any excess. In 2000, the Horticultural Research Institute ("HRI"), Biotechnology Trust of Zimbabwe, and academic research institutes including the University of Zimbabwe's Department of Crop Science, spearheaded efforts to create sweet potato varieties using tissue culture techniques for commercial production. ${ }^{151}$

Second, it was important to develop a complete chain of distribution for the new crop, which is a critical point that usually is neglected in developing countries. In the case study, the Wine Council developed a set of marketing strategies, from broadening local consumption to attracting tourists, to improve the market share. ${ }^{152}$ Agricultural adaptation in developing countries generally is concentrated on crop growing and seed resilience. If the distribution chain cannot be enhanced, crop replacement cannot be truly successful.

Apart from the distribution and trading, in a case like Zimbabwe where a major crop will be replaced, people's eating habits may require some change as well. An educational campaign that aims to teach people how to utilize sweet potatoes would be beneficial as well.

\section{-New crops grown in non-traditional areas}

A range of potential adaptation options exist across all food system activities, not just in food production; benefits also exist from potential innovations in food processing, packaging, transport, storage and trade. Traditional food systems that are centered on industrial agricultural production are seriously threatened by climate change effects.

On one hand, industrial agriculture requires a vast scale of land to grow crops and raise livestock, which means the owners suffer more losses than small-scale agriculture production under the climatic stress. On the other hand, resources and infrastructure required to operate an industrial agricultural system in some developing countries are impractical for

\footnotetext{
${ }^{151}$ Edward Mutandwa, Performance of Tissue-Cultured Sweet Potatoes Among Smallholder Farmers in Zimbabwe, http://www.agbioforum.org/v11n1/v11n1a05-mutandwa.htm (last visited June 23, 2014).

${ }^{152}$ See CT Farm Wine Development Council, Strategic Marketing Plan, available at http://www.ct.gov/doag/lib/doag/boards_commissions_councils/ct_farm_wine_delvp_council/strategic_marketing_plan.pdf.
} 
small-holder farmers. Thus, new growing areas need to be identified and developed, for instance by encouraging agriculture in every corner of cities.

Currently, urban agriculture is spreading all over the world. Based on the core idea that utilizing every available fragment of earth in the city to grow crops, urban agriculture has reconstructed a new type of food system, from food production, to food processing and distribution, which can help the agriculture sector adapt to climate change as well as relieve food insecurity more effectively.

\section{A. How Do The Projects Work?}

Growing food in non-traditional locations is a challenge for the government. Without proper comprehensive planning, urban agriculture could develop detrimentally, leading to various forms of environmental pollution.

Informed by European practices, the Seattle Green Factor program is a scoring system that displays landscape requirements developed by the Seattle Department of Planning and Development. The Department guides developers and designers in improving and increasing planted areas in new developments. ${ }^{153}$ A scoring system encourages green features, while allowing the flexibility to experiment with various combinations of elements to meet a specifiec minimum Green Factor score. ${ }^{154}$

\section{B. Implications for Further Replication}

The meaning of the Seattle scoring system is not merely limited to creating space for promoting urban agriculture. Its significance lies in integrating urban agriculture into comprehensive urban planning and future development. Meanwhile, its benefits can be maximized with combining other planning elements.

As mentioned above, generally, adaptation measures are adopted on a local and program basis, which indicates that comprehensive planning from an overall perspective may be absent. Since urban areas in developing countries are expanding rapidly, an orderly urban planning regime is required to coordinate different strategies and programs. The Seattle

\footnotetext{
${ }^{153}$ See Seattle's Department of Planning and Development, Seattle Green Factor, http://www.seattle.gov/dpd/cityplanning/completeprojectslist/greenfactor/whatwhy/ (last visited June 23, 2014).

${ }^{154}$ See Seattle's Department of Planning and Development, Green Factor Score Sheet, available at http://www.seattle.gov/dpd/cs/groups/pan/@pan/documents/web_informational/dpds021340.xlsx.
} 
scoring system sets up minimum scores for new development, while it lays out alternatives as flexible choices. It is relatively easy to replicate for developing countries.

\section{Interaction Between Sectors: The Water-Energy-Food}

\section{Nexus}

In the Section II, we displayed a series of adaptation practices based on a sector basis analysis (water, energy and food). These sectors do not always function independently. On the contrary, water, energy and food interact with each other actively, providing a significant additional path to design adaptation measures.

\section{A. Origin of The Nexus}

In 2011, a nexus approach was first proposed by the German Federal Government at the international level ${ }^{155}$ to "integrate management and governance", to "support the transition to a Green Economy", to improve "resource use efficiency" and to support "greater policy coherence" in the context of the Rio+20 summit." conceptual framework on the water-energy-food nexus in the same year as well. ${ }^{157}$ In 2012 , the International Centre for Integrated Mountain Development developed a framework that focuses on the nexus approach to better protect the environment and eco-services of the Himalayas and South Asia. ${ }^{158}$ Each of these three nexus concepts has its own emphases, but the core value of the nexus approach, common to all three, is about how to utilize scarce the

\footnotetext{
${ }^{155}$ In 2011, the first nexus international conference was held in Bonn, Germany. It was organized by the German Federal Government as "a specific German contribution to the UN Conference on Sustainable Development 'Rio2012'”. A conference paper called The Water, Energy and Food Security Nexus: Solution for the Green Economy lays the primary foundation on the background knowledge of a nexus approach. See The Water, Energy and Food Security Resource Platform, The Bonn Nexus Conference, http://www.water-energy-food.org/en/whats_the_nexus/bonn_nexus_conference.html (last visited on Jan. 22, 2014).

${ }^{156}$ Id.. See also the German Federal Government, The Water, Energy and Food Security Resource Platform, http://www.water-energy-food.org/en/whats_the_nexus/bonn_nexus_conference.html (last visited on Jan. 22, 2014). [ADJUST FONT]

${ }^{157}$ See The World Economic Forum Water Initiative, Water Security: The Water-Food-Energy-Climate Nexus, 2011, available at: http://www3.weforum.org/docs/WEF_WI_WaterSecurity_WaterFoodEnergyClimateNexus_2011.pdf.

${ }^{158}$ See International Centre for Integrated Mountain Development, Contribution of Himalayan Ecosystems to Water, Energy, and Food Security in South Asia: A Nexus Approach, 2012, available at: http://www.circleofblue.org/waternews/wpcontent/uploads/2012/07/icimodcontribution_of_himalayan_ecosystems_to_water_energy_and_food_security_in_south_asia-_a_nexus_appr-1.pdf.
} 
resources of water, energy and food more effectively, ${ }^{159}$ and to improve policy coordination and harmonization, to design a more effective regime compared to individualized methods.

Three indispensable elements, water, energy and food, establish a link that has vibrant interactions. It is clear to see that water is crucial for food production and energy generation and that energy is required for water distribution and modern agricultural measures, ${ }^{160}$ and both are required for food production. Sometimes there are conflicts, as between food production and energy development. For example, biomass and solar energy require large tracts of land that may deprive the areas available forfood proeduction. ${ }^{161}$ However, the complementary effect of energy and food exists as well. Growing food at some proper locations can reduce energy requirements by alleviating heat island effects. However, each interaction indicates a possibility to maximize the resource use efficiency as well as adaptation performance.

\section{B. Adaptation and the Nexus}

Since "climate policies can impact on water, energy and food security, and adaptation can in fact be maladaptive if not well aligned in a nexus approach and implemented by appropriately interlinked institutions," ${ }^{162}$ the water-energy-food nexus is important to climate change adaptation.

Although a number of global and regional conferences, workshops, and meetings on this nexus were held in 2011-2012, especially during the presentation phase for Rio+20 in

\footnotetext{
${ }^{159}$ The conference paper demonstrated that most conflicts happened between institutions associate with allocation and distribution of limited resources; thus it stressed that a new nexus approach should improve "sectoral" resource productivity and lead to "overall" benefit sharing. Seethe Water, Energy and Food Security Nexus: Solution for the Green Economy, 1112.

${ }^{160}$ As for the interactions between water, energy and food, the conference paper and some reports all give a detailed analysis and demonstration. See The Water, Energy and Food Security Nexus: Solution for the Green Economy, 18-27. See also Peter Hanlon, Robin Madel, Kai Olson-sawyer, Kyle Rabin, and James Rose, Food, Water and Energy: Know the Nexus, 8-9, available at http://www.gracelinks.org/media/pdf/knowthenexus_final_051513.pdf.

${ }^{161}$ A report conducted by a Spain-based non-profit showed that increased demand for biofuel production has driven farmers and forest communities from Brazil to Indonesia off their land, threatening those people's wellbeing and food security. See GRAIN, Land Grabbing for Biofuels Must Stop (2013), available at http://www.grain.org/article/entries/4653-land-grabbingfor-biofuels-must-stop.pdf. This phenomenon has not just appeared in Brazil; another policy brief indicated that it is a global issue. See IIED, Agricultural Land Acquisitions: A Lens on Southeast Asia, April 2012, available at http://pubs.iied.org/pdfs/17123IIED.pdf?.
}

${ }^{162}$ See The Water, Energy and Food Security Nexus: Solution for the Green Economy, 8. 
June $2012,{ }^{163}$ there is still no comprehensive cross-sectoral adaptive approach recognized by UNFCCC or its Conference of Parties. One of the most related documents to adaptation is Adaptation Assessment, Planning and Practice: An Overview From The Nairobi Work Programme on Impacts, Vulnerability and Adaptation to Climate Change. Yet it is noted that the nexus approach is only mentioned there and proposed by the International Water Management Institute ("IWMI") "for assessing the role of water and adaptive capacity of agro-ecosystem". 164

The regional level is active with regard to integrating the nexus approach into adaptation thinking. The Middle East and North Africa (the MENA region) uses water as a key drive to develop a strong capacity for anticipating and adapting impacts of climate change, such as to pfrevent food shortages. This regional cooperation has obtained some important results, including an action plan adopted by the Arab Ministerial Water Council ("AMWC"), implementation of climate change innovation measures through the Arab Center for the Studies of Arid Zones and Dry Lands (“ACSAD”) guidelines, and the creation of manuals for the region's national water ministries and institutions to adapt to climate change in their strategies and action plans. ${ }^{165}$

The nexus approach was adopted to help the Mekong River Basin adapt to climate change as well. In early 2000s, the adaptive approach to manage this region was still sectorbased, yet the trans-sector and transboundary approach inspired by the nexus started in 2010. ${ }^{166}$ Due to similar impacts of climate change that countries located along the Mekong River Basin are facing, this burgeoning nexus approach can advance information-sharing among Cambodia, Lao PDR, Thailand, and Vietnam.

\footnotetext{
${ }^{163}$ Livia Bizikova, Dimple Roy, Darren Swanson, Herry David Venema and Matthew McCandless, The Water-Energy-Food Security Nexus: Towards a Practical Planning and Decision-Support Framework For Landscape Investment and Risk Management, 5, 2013, available at: http://www.iisd.org/pdf/2013/wef_nexus_2013.pdf.

${ }^{164}$ See United Nations Framework Convention on Climate Change, Adaptation Assessment, Planning and Practice: An Overview From The Nairobi Work Programme on Impacts, Vulnerability and Adaptation to Climate Change, 41 (2010), available at: http://unfccc.int/resource/docs/publications/10_nwp_adap_assess_en.pdf

${ }^{165}$ See The Water, Energy and Food Security Resource Platform, Adaptation to Climate Change in the Water Sector in the MENA Region (ACCWaM), http://www.water-energy-food.org/en/practice/view__1108/adaptation-to-climate-change-in-thewater-se (last visited on Jan. 22, 2014). Stockholm Environment Institute also has research in the MENA region in the context of the nexus approach. See Magnus Benzie, Marion Davis and Holger Hoff, Climate Change, Water and Energy in the MENA Region: Why a 'Nexus' Approach is Crucial for Mitigation and Adaptation, 2012, available at: http://www.seiinternational.org/mediamanager/documents/Publications/Climate/SEI-DB-2012-MENA-climate-nexus.pdf.

${ }^{166}$ See Nguyen Huong Thuy Phan, A Nexus of Adaptation: Climate Change Implications on the Water-Food-Energy Nexus of the Lower Mekong Basin, available at: http://www.mrcmekong.org/assets/Events/Mekong2Rio/4.2b-A-nexus-ofadaptation-Implications-of-climate-change-on-water-food-energy-nexus-Phan.pdf
} 
As for the national level, it is common to see that countries integrate the nexus into adaptation measures in three ways: (1) Some countries such as the Ukraine, attempt to "increasing interdependencies between food, energy, and water security" by launching a joint research project created by national research institutes and international organizations; ${ }^{167}$ (2) Countries like Japan provide funding for nexus pilot projects as research programs, ${ }^{168}$ and; (3) Ghana's National Climate Change Strategy, known as the "Akropong Approach", concentrates on the connection between climate adaptation and landscapes as well as addresses the nexus of food security, water, forest and energy within a landscape context. ${ }^{169}$ It is worth mentioning that the three ways illustrated above can be used at the same time as well.

In fact, the local /city level is the most robust level by introducing the nexus process in its adaptation regime design and governance. The main reason is because adaptation measures are place-based, which makes it easier for local level to find nexussolutions. Also, it is necessary to understand that local government stands on the front line with regard to adaptation measures. The government at this level enjoys high flexibility to adjust and accept new governance models.

\section{Types of the Nexus in Practice}

Unlike conventional policy-developing ways that operate mostly in isolation from one another (which leads easily to conflicts), the nexus approach can largely reduce policy contradictions and resolve conflicts between governmental agencies. Additionally, practices under different contexts can have complementary effects. In other words, even though

\footnotetext{
167 They are five non-profit institutes of the National Academy of Sciences of Ukraine (NASU) and International Institute for Applied Systems Analysis (IIASA). See IIASA, Integrated Modeling of Robust Solutions for Food, Energy, and Water Security Management, http://www.iiasa.ac.at/web/home/research/researchProjects/Integrated-Modeling-of-RobustSolutions-for-Food--En.en.html (last visited on Jan. 22, 2014).

${ }^{168}$ Currently, there is a five-year project called the "Futurability Initiatives" run by the Research Institute for Humanity and Nature that tries to analyze the nexus from the perspective of human -environment security, particularly how to "optimize governance and management with these inter-connected needs." The project picked the coastal region of the Ring of Fire as the pilot subject. This project is more comprehensive and almost reaches every aspect. See Research Institute for Humanity and Nature (RIHN) Core Research Project, Human-Environmental Security in the Asia-Pacific Ring of Fire: Water-EnergyFood Nexus, http://www.chikyu.ac.jp/wefn/english/index.html (last visited on Jan. 22, 2014).

${ }^{169}$ See José Urrea y Lucy Holt, Combined Solutions to Strengthen Adaptation, CIGAR Research Program on Climate Change, Agriculture and Food Security, Nov. 21, 2013, http://ccafs.cgiar.org/blog/combined-solutions-strengthenadaptation\#.UuBFznCS2IU (last visited on Jan. 22, 2014).
} 
adaptation measures may only touch one or two elements from the appearance, all natural resources of the nexus would be embraced by appropriate policy designs.

It is recognized that water is the priority element to emerge from the water-energy-food nexus approach and it is the prerequisite of the nexus. In some cases, one or two elements can be highlighted and severed as a leading element to link adaptation governance. For example, the nexus sometimes can be broken into the water-energy or water-food sectprs. The energy element stands out with regard to energy generation from such as power plants and dam operation. While in the process of food production, particularly in urban agriculture, the food element takes the position to better maximize the benefits of the nexus. However, it is impossible for the water element to be absent from the nexus.

\begin{tabular}{c|c}
\hline Leading Elements of The Nexus & Sample Practices \\
\hline Water & Basin Resource Management (Reservoir and \\
Energy & Dam Operation) \\
Food & Power Plants, Biofuel \\
& Urban Agriculture, Green Infrastructure \\
\hline
\end{tabular}

Figure-2

Here is an example from San Francisco. Similar to many cities in the U.S., the lead agency of urban agriculture in San Francisco is the Recreation and Park Department ("RPD"). Yet other agencies' active participation should be highlighted as well.

First, the Public Utilities Commission ("PUC”), as San Francisco's energy regulator, gets involved in the urban agriculture very actively. The PUC does not only provide funding to support two farms on land it owns, but also serves as a key agency to work with RPD to develop urban agriculture. Meantime, the PUC is the responsible department for water protection as well. ${ }^{170}$ In order to build urban agriculture, the PUC regulates water conservation requirements for urban agriculture, including interpreting San Francisco's Water

\footnotetext{
${ }^{170}$ See Services of the San Francisco Public Utilities Commission, About Us, http://www.sfwater.org/index.aspx?page=161 (last visited on Feb. 2, 2014).
} 
Efficient Irrigation Ordinance. ${ }^{171}$ This design is significant to bond the interests of two agencies, which encourage food-water-energy nexus linkage.

Second, RPD houses a program for the city that would coordinate the work of a wide range of agencies to "generally enhance and increase urban agriculture in San Francisco". ${ }^{172}$ On one hand, this program can embrace relevant agencies besides the water and energy department to participate in developing a sustainable system. On the other hand, it can solve the capital problem. The new ordinance requires city agencies to advocate for state and federal funding, collect data related to urban agriculture, support gleaning programs, identify opportunities to use urban agriculture for job training and employment, and ensure that existing farm and garden spaces are used fully. In order to reach these goals, RPD hires fulltime staff to coordinate the work. The underlying reason is that many city agencies supported urban agriculture, but when the public had difficulty getting assistance, there was no person or agency to take a clear responsibility.

Besides positioning the staff, the agency is tasked with providing accountability. The program is required to send annual reports to the Board of Supervisors that include evaluation of a variety of metrics, including an accounting of how city funds have been spent. From above, it can be seen that the seed of urban agriculture has been successfully planted in the city organism.

From above, the nexus is well designed to work as a whole in San Francisco as well as to outreach other relative city departments to obtain valuable resources to support the nexus development.

\footnotetext{
${ }^{171}$ See Services of the San Francisco Public Utilities Commission, Water Efficient Landscape, http://sfwater.org/index.aspx?page=689 (last visited on Feb. 2, 2014).

${ }^{172}$ San Francisco Administrative Code Chapter 53.
} 


\section{Conclusion}

Adaptation to climate change is essential and urgent, particularly for low lying areas and island countries. Adaptation plans need to be designed appropriate to the needs and conditions of each country and area. But certain essentials are obvious.

Necessary requisites include adequate planning, involvement of those affected, collaboration among the departments of government, adequate training of responsible personnel, involvement and education of the affected public.

The most important adaptation measures are those to protect populations from sea level rise and extreme weather events. These measures require early warning systems and relocation planning that can be very difficult, particularly if resettlement in another country is required. The problem of climate refugees needs priority attention.

Other adaptation measures can include natural protection of coastlines and protective barriers as with planting mangrove trees and creation of oyster shell barriers. Agriculture can be relocated and revised to include climate resistant crops. Electricity production can be decentralized and generation distributed with promotion of renewable energy. Where a grid still is necessary it can be strengthened. Water can be much better utilized through efficiency measures, the collection of rainwater, and the use of Gray water.

Adaption plans should recognize the important nexus between water, food and energy. Recognizing this interrelationship can greatly strengthen the effectiveness of adaptation measures.

Today there are examples of all these measures from which nations and municipalities can benefit, many of which are included in the case studies presented.

The most important requisite for adaptation is the will to act and international recognition of the urgency of action. As has been well demonstrated by the IPCC and many studies, it will be far cheaper to act now than to have to pay the incredible costs of inaction. 